\title{
Okul Müdür Yardımcılarının Görevlerinden Ayrılma Nedenleri $^{1}$
}

\begin{tabular}{lccc}
\hline MAKALE TÜRÜ & Başvuru Tarihi & Kabul Tarihi & Yayın Tarihi \\
Araştırma Makalesi & 29.12 .2018 & 04.10 .2019 & 04.10 .2019 \\
\hline
\end{tabular}

Mesut Demirbilek (iD ${ }^{2}$ ve Ayşen Bakioğlu

Marmara Üniversitesi

Öz

Araştırmanın amac1, müdür yardımcılığı görevinden kendi isteğiyle ayrılan okul yöneticilerinin görevden ayrılma nedenlerinin incelenmesidir. Nitel araştırma yöntemlerinden olgubilim deseniyle yürütülen çalışmanın verileri, yarı yapılandırılmış görüşme formu kullanılarak elde edilmiştir. Ölçüt örnekleme yoluyla İstanbul'un altı ilçesinde önceden müdür yardımcılığı yapmış ve istifa ederek öğretmenliğe dönmüş 21 öğretmen ile görüşülmüştür. Görüşmelerden elde edilen veriler kodlanmış ve temalar altında içerik analizi gerçekleştirilmiştir. Araştırmada müdür yardımcılığından istifa edenlerin çoğunluğunu erkek yöneticiler oluşturmakta olup, çoğunluğu kariyerlerinin başlangıç basamağında (1-3 yıl) istifa etmişlerdir. Müdür yardımcılığını bırakanların büyük bir bölümü idari evrak işlerinin fazla olduğunu, görev alanı dıșı işlerle uğraştıklarını; önlerinde kariyer engeli olarak mülakat ve siyasi-ideolojik engellerin olduğunu, müdür yardımcılığını kariyer olarak görmediklerini belirtmişlerdir. Aynı zamanda istifa etmelerinde dış etken olarak aile kaynaklı nedenlerin, iç etken olarak iş yükünün etkili olduğunu; öğretmenlerle ilişkileri bakımından öğretmenlere ve diğer personele iş yaptırmakta zorluk yaşadıklarını, öğretmen ile müdür arasında kaldıklarını; müdür yardımcılığının maddi getirisinin olmadığını, izin haklarının az olduğunu ve kullanamadıklarını, uzun çalışma sürelerine sahip olduklarını belirtmişlerdir. Yine müdür yardımcılığı görevinde zihinselduygusal tükenme yaşadıklarını ve çoğunluğu müdür yardımcılığına geri dönmeyi düşünmediğini belirtmiştir. $\mathrm{Bu}$ anlamda müdür yardımcılığından istifa etme gerekçe ve boyutları bakımından okul içi etkenlerin ve kariyer haklarının daha baskın olması araştırma açısından dikkate değerdir.

Anahtar sözcükler: Müdür yardımcısı, istifa, yönetici, kariyer, müdür yardımcılığı kariyeri.

${ }^{1} \mathrm{Bu}$ çalışma 6-8 Eylül 2018 tarihlerinde Amasya'da düzenlenen Uluslararası Öğrenme, Öğretim ve Eğitim Araştırmaları Kongresinde sözlü bildiri olarak sunulmuştur.

${ }^{2}$ Sorumlu Yazar: Doktora Öğrencisi, Atatürk Eğitim Fakültesi, Eğitim Bilimleri Bölümü, Eğitim Yönetimi ve Denetimi Anabilim Dal1, E-posta: demirbilekmesut@gmail.com, https://orcid.org/0000-0002-75707807

${ }^{3}$ Prof. Dr., Atatürk Eğitim Fakültesi, Eğitim Bilimleri Bölümü, Eğitim Yönetimi ve Denetimi Anabilim Dalı, E-posta: abakioglu@ marmara.edu.tr, https://orcid.org/0000-0002-2571-1533 
Okul yöneticileri çok çeşitli görevler ile uğraşmaktadırlar. Bu görevler, öğretim etkinliğinin yürütülmesi ve eşgüdümü sağlamak, dış paydaşlarla, ailelerle iletişim kurmak, mali yönetim gibi pek çok konuyu kapsamaktadır. Bununla birlikte okul yöneticileri, personel yönetimi ve yasal sorumlulukların yanı sıra eğitim bilimsel tutarlılıktan da sorumludurlar. Diğer yandan okul yöneticileri eğitim bürokrasisi ve okulun arka planında bulunan diğer destek öğeleriyle işbirliği yapmak ve yenilikleri uygulamada öncü bir role sahip olmak zorundadırlar (Friedman, 2002).

Okul liderlerinin bu sorumlulukları, hızlı değișen demografik öğeler, teknolojik ilerlemeler, okulların azalan finansal destekleri, değişen beklentilerden dolayı daha fazla karmaşık duruma gelmiş ve daha zorlayıcı olmuştur. Aynı zamanda okul yöneticileri tarafından sadece etkili bir liderlik ile sağlanabilecek olan öğrenmeyi arttırma hedefi doğrultusundaki hesapverebilirlik ve kanıt sunma, yöneticileri zorlamaktadır (Calman, 2010; Collinson ve Cook, 2007; Demarest, 2011; Fink, 2010; Green, 2010; Hawley, 2007 akt., Searby, Browne-Ferrigno ve Wang, 2016; Spillane ve Lee, 2014). Bunun dışında ücretlerin azlığı, artan sorumluluklar, yoğun iş yükü ve hesapverebilirlik açısından dış baskılar da okul yöneticilerinin işe olan bağlılıklarını zayıflatmaktadır (Fenwick, 2000; Lacey, 2002; Yerkes ve Guaglianone, 1998 akt., Shoho ve Barnett, 2010).

Yine okul yöneticilerinin, liderlik, gelişimi sağlama, personeli güdüleme gibi sorumlulukları da bulunmaktadır. Eğitim yöneticilerinin verdikleri kararlar ve yaptıkları uygulamalar önemli bir yere sahiptir. Bunlar, yöneticilerin okullarının ve bir lider olarak kendilerinin başarısını da etkilemektedir. Özellikle yöneticiliğin ilk yıllarında okul yöneticileri, okullarda birçok değişikliklerle yüz yüze kalmakta ve bu durum yöneticilere olumsuz yansımaktadır (Burkhauser, Gates, Hamilton ve Ikemoto, 2012). Örneğin Bakioğlu'na (1994) göre okul yöneticileri, özellikle kariyerlerinin başlangıç evresinde önceki yönetici zamanında benimsenen değer yargılarını değiştirme, günlük işlemler ile uğraşma, halkla ilişkiler, öğretim programı ve veliler ile ilgili sorunları, büyük zorluklar olarak görmekte ve belirsizlik, şaşkınlık yaşamakta; bağlantısızlık evresinde güven, enerji kaybı ve yorgunluk artmakta, artan iş yükü yöneticilerde stres, duygusal ve fiziksel kötüleşme yaratmaktadır. Yine Daresh ve Playko’ya (1994) göre yeni okul yöneticileri, (1) yöneticilik ve otoritenin kullanımı gibi kim olduklarını anlamalarına ilişkin rollerini açıklığa kavuşturma, (2) bir şeylerin nasıl yapılacağı ile ilgili sınırlı teknik uzmanlıkları, (3) mesleğe ve bireysel okul sistemine uyum ile ilgili zorluklar gibi çeşitli sorunlarla yüz yüze kalmaktadırlar. $\mathrm{Bu}$ anlamda müdür yardımcılarının da dahil olduğu okul yöneticilerinin kariyer aşamalarını belirlemeye yönelik yapılan tüm çalışmalarda (Hart, 1993; Reeves, Moos, ve Forrest, 1998; Weindling, 2000) aşamaların ismi ve sayısı farklı olmasına karşın yöneticiliğe giriş sonrası ilk yılların yarattığı rol belirsizliği ve şaşkınlığının neden olduğu yöneticilik görevini bırakma eylemi, tüm çalışmalarda ortaktır. Bu durum okul yöneticiliğindeki ilk yılların, göreve devam etme kararını etkilediğini göstermektedir. 
Nitekim öğretmenler, öğretmen olarak deneyimlemedikleri yeni görev ve zorluklara sahip olan ilk resmi okul liderliği rolüne müdür yardımcılığı göreviyle başlayıp sayısız ve çeşitli sorumluluklardan dolayı kişisel ve mesleki yaşamlarını dengelemede zorluklar yaşamaktadırlar (Fields ve Egley, 2005; Hausman, Nebeker, McCreary ve Donaldson, 2001). Öğretim rolünden müdür yardımcılığı görevine geçiş müdür yardımcılarının, okulda çeşitli çatışmalar yaşamasına neden olabilmektedir. Bunun nedeni ise müdür yardımcılarının önceden öğretmen olarak sadece öğrencilerle çalışırken yöneticilik görevini aldıktan sonra düzenli olarak okul personeli, aileler ve diğer okul yöneticileri ile iletişim kurmak zorunda kalmalarıdır (Fields ve Egley, 2005). Michel (1996), bu değişimi yalıtılmış sınıf ortamından daha açık ve etkileşimli idari atmosfere hareket etmek olarak tanımlamaktadır.

Bu doğrultuda Barnett, Shoho ve Oleszewski (2012), okulların akademik başarı istekleriyle karşı karşıya kaldıkça müdür yardımcılarının rolünün geleneksel disiplin ve yönetici anlayışından okulun öğretim programının geliştirilmesinin ön plana çıktığ bir anlayışa doğru evrimleşmesi gerektiğini ve bu anlamda iş tanımlarının daha karmaşık bir duruma geldiğini belirtmektedir. Müdür yardımcılarının rolleri ve görevleri, müdürlerin yükünü hafifletmekten, öğretmenlere yönetsel destek sağlamaya, öğrencilerin refahıyla ilgilenmeye kadar uzanmaktadır. Aynı zamanda müdür yardımcılarının birçok iş tanımı açık olmayıp müdür yardımcılarının sorumlulukları okula ve bölgelere göre değişebilmektedir (Glanz, 1994; Harvey, 1994). Örneğin İngiltere ve Galler'deki müdür yardımcıları, sorumluluklarını gülünç, akıllara durgunluk veren, olanaksız ve sinir bozucu olarak tanımlamışlardır (Webb ve Vulliamy, 1995).

$\mathrm{Bu}$ yoğun ve zorlu sorumluluk sürecinde okul yöneticilerinde stres ve tükenmişliği yaratan bireysel ve bağlamsal değişkenler bulunmakta olup özellikle çalışma koşulları, kurumsal özellikler, öğrenci davranışları, profesyonel tanınma ve itibar gereksinimleri, uzmanlık düzeyi, öğretmen-öğrenci oranı, kaynak eksikliği, meslektaşlarıyla ilişkiler ve sosyal destekten oluşan bağlamsal değişkenler bu stres ve tükenmişlik öğelerini arttırmaktadır (Cano-García, Padilla-Muñoz, ve Carrasco-Ortiz, 2005). Bazı noktalarda okul yöneticileri çeşitli görevleriyle ilgili başarı beklentilerini karşılayamayacaklarını düşünmekte ve hayal kırıklığına uğramış, tükenmiş ve başarısız hissedebilmektedirler. Bazıları, okul yöneticiliğinden vazgeçmeyi düşünürken bazıları ise savaşmayı veya işyerlerinde onlara dayatılan yüklere katlanmayı öğrenmektedirler (Friedman, 2002).

Yine okul içi ve dışı baskı öğelerinin etkisiyle okul yöneticiliği rolünde zamanla zedelenmeler ve eksilmeler yaşanmakta ve bu durum onlarda kariyer hedeflerinden vazgeçmeye kadar uzanabilen stres, kaygı ve baskı duygularını yaratmaktadır. Örneğin Gajda ve Militello (2008) tarafindan ABD'nin Massachusetts eyaletinde yapılan araştırmada çalışmaya katılan okul yöneticilerinin üç temel nedenden konumlarını bırakmayı düşündükleri belirlenmiştir. Bunlar, (1) yöneticiliğgin stresli bir iş olması, (2) maaşın, görevin sorumluluklarına göre düşük olması ve (3) işin karmaşık ve zaman istemesidir. Yine gelecek beş yılda ayrılmayı düşünenlerin \% 11 'i 
ayrılma isteklerinin temel nedeni olarak öğretime odaklanmak için çok az zamana sahip olmak olarak açıklamışlardır.

Ülkemizde okul müdür yardımcılarının görevleriyle ilgili sorumlulukları okul müdürü tarafından belirlenmektedir (Milli Eğitim Bakanlığı-MEB İlköğretim Kurumları Yönetmeliği, 2014). Bu durum, müdür yardımcılarının, okuldan okula değişebilen, esnek, kötüye kullanmaya açık, farklı ağırlıklarda rol ve sorumluluk üstlenmelerine neden olmakta ve görev tanımlarında belirsizliğe yol açmaktadır. $\mathrm{Bu}$ durum ülkemizde yapılan araştırmalara da yansımıştır. Örneğin, Köse (2018), yaptı̆̆ 1 çalışmada müdür yardımcılarının görev alanlarıyla ilgili bir çok sorun yaşadığını; Konan, Yılmaz ve Bozanoğlu (2017), müdür yardımcılarında zamanla duygusal davranma, minnet duygusu, iş yükü oluşması gibi olumsuzlukların meydana gelebileceğini; Özalp, Yirci ve Kocabaş (2016), müdür yardımcılarının iş doyumunda, okul müdürünün sergileği danışmanlığın etkili olduğunu; Karahan (2019), resmi okul yöneticilerinin yetki kullanırken daha çok sorun yaşadığını; Günay ve Özbilen (2018), öğretmenlerin çoğunluğunun okul yöneticiliğini çeşitli nedenlerden dolayı (doyum elde etmeme, uzun çalışma süresi ve sorumluluk gibi) istemediklerini bulgulamışlardır. Bu yönüyle ülkemizde devlet okullarında görev yapan müdür yardımcıları, bir çok sorun ile karşı karşıya kalmakta ve bu sorunlar, istifa etme gerekçelerini oluşturmaktadır. Bu gerekçelerin ortadan kaldırılması için müdür yardımcılarının istifa etme nedenlerinin incelenmesi bu araştırma açısından önem taşımaktadır. Bu araştırmanın amacı, okul müdür yardımcılığından kendi isteğiyle ayrılan okul yöneticilerinin ayrılma nedenlerinin incelenmesidir.

\section{Yöntem}

Bu başlık altında araştırmanın deseni, çalışma grubu, veri toplama araçları ve verilerin analiz yöntemi ele alınmıştır.

\section{Araştırma Modeli}

Araştırma, nitel araştırma yöntemlerinden olgubilim deseni ile yürütülmüştür. Olgubilim deseni, farkında olduğumuz fakat derinlemesine ve ayrıntılı bir anlayışa sahip olmadığımız olgulara odaklanmaktadır (Yıldırım ve Şimşek, 2011).

\section{Çalışma Grubu}

Çalışma grubunun belirlenmesinde amaçlı örnekleme yöntemleri arasında yer alan ölçüt örnekleme yöntemi kullanılmıştır. Ölçüt örnekleme yönteminde temel amaç önceden belirlenmiş ölçüte dayanan durumların çalışılmasıdır. Bu ölçüt, araştırmacı tarafından oluşturulabilir veya daha önceden hazırlanmış bir ölçüt listesi kullanılabilir (Yıldırım ve Şimşek, 2011). Araştırmada çalışma grubunu oluşturan temel ölçüt, devlet okullarında müdür yardımcılığı yaparken istifa edilmesidir. Araştırma dönemi sürecinde ulaşılan katılımcıların bulunduğu ilçelerde kaç müdür yardımcısının istifa ettiği bilgisine ulaşılamamış olup, bu nedenle ilgili katılımcılara ulaşmak için aynı zamanda kartopu örnekleme yöntemi kullanılmış, katılımcı öğretmenlerin ilişkileri kullanılarak diğer katılımcılara ulaşılmıştır (Yazıcıoğlu ve Erdoğan, 2004). 
Araştırma kapsamında, İstanbul İli Anadolu yakasında bulunan Çekmeköy, Sancaktepe, Ümraniye, Üsküdar, Kartal, Ataşehir ilçelerindeki devlet okullarında öğretmen olarak görev yapan fakat önceden çeşitli ilçelerde müdür yardımcılığı yapmış ve istifa etmiş 21 öğretmen ile görüşülmüştür. Çalışma gurubunu oluşturan dağılım şu şekildedir:

Tablo 1

İstifa Ederek Öğretmenliğe Geri Dönen Müdür Yardımcılarına İlişkin Demografik Bilgiler

\begin{tabular}{|c|c|c|}
\hline \multicolumn{2}{|l|}{ Demografik Değişkenler } & Sayı \\
\hline \multirow{2}{*}{ Cinsiyet } & Erkek & 13 \\
\hline & Kadın & 8 \\
\hline \multirow{3}{*}{ Yaş Aralığ 1} & $20-30$ & 4 \\
\hline & $31-40$ & 9 \\
\hline & $41-50$ & 8 \\
\hline \multirow{9}{*}{ Alan } & Sinıf Öğretmenliği & 12 \\
\hline & Türk Dili ve Edebiyatı Öğretmenliği & 2 \\
\hline & Türkçe Öğretmenliği & 1 \\
\hline & Okul Öncesi Öğretmenliği & 1 \\
\hline & Sosyal Bilgiler Öğretmenliği & 1 \\
\hline & Felsefe Öğretmenliği & 1 \\
\hline & Müzik Öğretmenliği & 1 \\
\hline & Biyoloji Öğretmenliği & 1 \\
\hline & Matematik Öğretmenliği & 1 \\
\hline \multirow{5}{*}{ Öğretmenlik Deneyimi } & $0-5$ Y1l & 3 \\
\hline & 6-10 Y1l & 3 \\
\hline & $11-15 Y_{11}$ & 7 \\
\hline & $16-20 \mathrm{Y} 1 \mathrm{l}$ & 3 \\
\hline & 21-25 Y11 & 5 \\
\hline \multirow{6}{*}{$\begin{array}{l}\text { Müdür Yardımcılığını } \\
\text { Bıraktığı İlçe }\end{array}$} & Çekmeköy & 8 \\
\hline & Sancaktepe & 7 \\
\hline & Ümraniye & 3 \\
\hline & Kartal & 1 \\
\hline & Ataşehir & 1 \\
\hline & Üsküdar & 1 \\
\hline \multirow{4}{*}{$\begin{array}{l}\text { İstifa Ettiği Dönemdeki } \\
\text { Yöneticilik Deneyimi }\end{array}$} & 1-3 Y1l & 12 \\
\hline & 4-8 Yil & 5 \\
\hline & 8-12 Y11 & 3 \\
\hline & 12 y1l üstü & 1 \\
\hline \multirow{4}{*}{$\begin{array}{l}\text { Kaç Okulda Müdür } \\
\text { Yardımcılığ1 Yaptığ1 }\end{array}$} & 1 Okulda & 11 \\
\hline & 2 Okulda & 8 \\
\hline & 3 Okulda & 1 \\
\hline & 4 Okulda & 1 \\
\hline
\end{tabular}


Tablo 1 (devam)

\begin{tabular}{|c|c|c|}
\hline \multicolumn{2}{|l|}{ Demografik Değişkenler } & Sayı \\
\hline \multirow{4}{*}{$\begin{array}{l}\text { Müdür Yardımcılığını } \\
\text { Bıraktığı Okul Türü }\end{array}$} & İlkokul & 11 \\
\hline & Ortaokul & 6 \\
\hline & Anadolu Lisesi & 2 \\
\hline & Meslek lisesi & 2 \\
\hline \multirow{3}{*}{$\begin{array}{l}\text { Müdür Yardımcılığını } \\
\text { Bıraktığı Okulun Öğrenci } \\
\text { Sayısı }\end{array}$} & 0-999 Öğrenci & 6 \\
\hline & 1000-1999 Öğrenci & 13 \\
\hline & 2000-2999 Öğrenci & 2 \\
\hline \multirow{3}{*}{$\begin{array}{l}\text { Müdür Yardımcılığını } \\
\text { Bıraktığ1 Okulun } \\
\text { Öğretmen Sayıs1 }\end{array}$} & 0-30 Öğretmen & 5 \\
\hline & 31-50 Öğretmen & 9 \\
\hline & 51-70 Öğretmen & 7 \\
\hline
\end{tabular}

Tablo 1'de görüldüğü üzere görüşme yapılan öğretmenlerin 13'ü erkek, sekizi kadındır; çoğunluğu (9) 31-40 yaş arasında olup branş olarak da sınıf öğretmenlerinden (12) oluşmaktadır. Mesleki deneyimlerine bakıldığında çoğunluğu (7) 11-15 yil öğretmenlik deneyimine; istifa ettiği dönemdeki yöneticilik deneyiminde ise (12) 1-3 yıl arası yöneticilik deneyimine sahiptir. Aynı zamanda çoğunluğu (11) sadece bir okulda müdür yardımcısı olarak çalışmış ve (11) ilkokulda görev yaparken müdür yardımcılığını bırakmış olup, müdür yardımcılığını bıraktığı okulun öğrenci sayısına bakıldığında 1000-1999 arasında öğrenci sayısına $(f=13)$ ve 31-50 öğretmen sayısına (f = 9) sahiptir.

\section{Veri Toplama Araçları}

Olgubilim araştırmalarında ele alınan olgular veya konularla ilgili olarak deneyimlerin ayrıntılı biçimde betimlenmesi ve resmedilmesi amaçlanmaktadır ve olgubilim araştırmalarında başlıca veri toplama yöntemi görüşmedir (Patton, çev. 2014; Yıldırım ve Şimşek, 2011). Bu nedenle araştırmada, verilerin toplanması amacıyla görüşme yöntemi kullanılmıştır. Veriler, müdür yardımcılığından istifa ederek öğretmenliğe dönen katılımcıların istifa etme nedenlerine yönelik görüşlerini öğrenmek amacıyla ilgili alanyazın taranarak hazırlanan 11 açık uçlu sorudan oluşan yarı yapılandırılmış görüşme formu ile elde edilmiştir. Görüşme formundaki sorular şunlardır:

1. Demografik Bilgiler:

a) Kaç yaşındasınız?

b) Öğretmenlik alanınız nedir?

c) Öğretmenlik deneyim yılınız nedir?

d) Müdür yardımcılığını hangi ilçede görev yaparken bıraktınız?

e) Müdür yardımcılığı görevini kaç yıl yöneticilik yaptıktan sonra biraktınız? 
f) Kaç okulda müdür yardımcılığı yaptınız.

g) Müdür yardımcılığını bıraktığınız okul türü nedir?

h) Müdür yardımcıllğını bıraktığınız okulun öğrenci mevcudu ne kadardı?

i) Müdür yardımcılığını bıraktığınız okulun öğretmen mevcudu ne kadardı?

2. Müdür Yardımcılığı görevinizi bırakmanıza neden olan görev tanımınızla ilgili nedenler nelerdir, açıklayabilir misiniz?

3. Müdür Yardımcılığı görevinizi bırakmanıza neden olan bu görev ile ilgili kariyer engelleriniz nelerdir, açıklayabilir misiniz?

4. Müdür Yardımcıllğg görevinizi bırakmanıza neden olan okul içi ve dışı etkenleri açılayabilir misiniz?

a) Okul içi etkenler nelerdir?

b) Okul dışı etkenler nelerdir?

5. Müdür Yardımcıllğı görevinizi bırakmanıza neden olan ast-üst ilişkisinden kaynaklı nedenler var mıdır, var ise nelerden oluşmaktadır?

6. Müdür Yardımcılığı görevinizi bırakmanızın nedenleri arasında iş yükünün (görev yükü) etkili olduğunu düşünüyor musunuz, açıklayabilir misiniz?

7. Müdür Yardımcıllğı görevinizi bırakmanızın nedenleri arasında personel ilişkilerinden ve okul kültüründen kaynaklı etkenler var mıdır, aç̣klayabilir misiniz?

8. Müdür Yardımcıllı̆ı görevinizi bırakmanız gerektiği konusunda sizi ikna etmeye çalışan veya sizi bu konuda etkilemiş olan kişi ve kişiler var mıdır, var ise hangi noktalarda sizi ikna etmişlerdir, açılayabilir misiniz?

9. Müdür Yardımcılı̆̆ı görevinizi bırakmanıza neden olan görev alanınızla ilgili haklarınız ve sorumluluklarınız bağlamında nedenler nelerdir, açıklayabilir misiniz?

10. Müdür Yardımcıllğı görevinizden ayrılarak öğretmenliğe geri dönüş yaptığınızda kariyer yaşamınızda ne tür olumlu-olumsuz değişiklikler oldu, açıklayabilir misiniz?

11. Yöneticilik görevinize tekrar geri dönmeyi düşünüyor musunuz, dönmeyi düşünürseniz yöneticilik ile ilgili beklentileriniz ve yapmak istedikleriniz nelerdir, açılayabilir misiniz?

Görüşme formundaki açık uçlu soruların geçerli ve amaca uygun nitelik ve kapsamda olup olmadığını belirlemek amacıyla Eğitim Yönetimi alanında uzman olan iki öğretim üyesinden görüş alınmış ve kapsamın değerlendirilmesi istenmiştir. Uzman değerlendirmesindeki ortak görüş doğrultusunda iki soruda düzeltmeye 
gidilmiştir. Aynı zamanda İstanbul ili Çekmeköy ilçesinde bulunan biri ilkokul biri de ortaokulda görev yapan ve müdür yardımcılığından istifa etmiş iki öğretmene pilot uygulama gerçekleştirilmiştir. Pilot uygulama sonucunda elde edilen veriler kodlanmış ve sunulan görüşlerden elde edilen kodların tutarlı ve birbirine yakın olduğu görülmüştür. Görüşme formuna son biçimi verildikten sonra araştırma kapsamındaki katılımcılara uygulanmıştır. Araştırmaya ilişkin görüşmeler 2017 Kasım-Aralık aylarında yapılmıştır. Görüşmeler yüz yüze gerçekleştirilmiş, görüşme sırasında katılımcılar, görüsşme ile ilgili olarak bilgilendirilmiş, veri kaybını önlemek amacıyla izin alınarak kayıt cihazı kullanılmıştır.

\section{Verilerin Analizi}

Araştırma verilerinin analizinde içerik analizi tekniği kullanılmıştır. İçerik analizinde temel amaç, toplanan verileri açıklayabilecek kavramlara ve verilere ulaşmaktır. Veriler daha derin bir işleme sokulur. İçerik analizinde birbirine benzeyen veriler, belirli kavramlar ve temalar çerçevesinde bir araya getirilerek okuyucunun anlayabileceği bir biçimde düzenlenerek yorumlanır. Ayrıca içerik analizinde fikir, konu ve kavramları belirtmek üzere alıntılara da yer verilmektedir (Yıldırım ve Şimşek, 2011). Görüşmelerden elde edilen ses kayıtları dinlenerek yazıya aktarılmış ve Nvivo 11.0 programı ile yazıya aktarılan görüşler iki uzman tarafından ayrı ayrı kodlanmış ve bu kodlar daha sonra belirli kategori ve temalar altında analiz edilmiştir. İki uzman tarafından yapılan kodlama ve kategorilendirme-temalandırma işleminin birbirleriyle büyük oranda tutarlı olduğu görülmüştür. Ayrı düşülen kodlarda ise iki uzman biraraya gelerek fikir birliğine varılmıştır (Creswell, çev. 2013). Bulguların güvenirliliğinin sağlanması açısından elde edilen kodlar ve temalar, daha önce görüşme yapılan iki katılımcının (Y4, Y7) görüşlerine sunulmuş ve katılımcı dönütlerinin, elde edilen bulgularla uyumlu olduğu görülmüştür. Araştırmada analizlerin, bulguların ve alıntıların ifade edilmesinde görüşülen müdür yardımcılığından istifa etmiş öğretmenlere, birer kod numarası verilerek $(\mathrm{Y} 1, \mathrm{Y} 2, \ldots)$ açıklamalar yapılmıştır. Kodlamalarda $Y$ harfi müdür yardımcılığı görevinden istifa etmiş olan öğretmenleri, sayılar ise katılımcı numarasını belirtmektedir.

\section{Bulgular}

$\mathrm{Bu}$ başlık altında müdür yardımcılığından ayrılan öğretmenlerin ayrılma nedenlerine ilişkin bulgular ele alınmıştır.

\section{Görev Tanımından Kaynaklanan Nedenler}

Müdür yardımcıllığından ayrılan öğretmenlerin görev tanımından kaynaklanan nedenlere ilişkin görüşleri Tablo 2'de yer almaktadır. 
Tablo 2

Müdür Yardımcılı̆̆ından Ayrılan Öğretmenlerin Görev Tanımından Kaynaklanan Nedenlere Ilişskin Görüşleri

\begin{tabular}{|c|c|c|c|}
\hline Temalar & Alt Temalar & Sayı & Katılımcılar \\
\hline \multirow{5}{*}{ 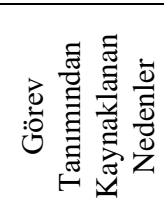 } & İdari evrak işlerinin fazlalığ 1 & 12 & $\begin{array}{l}\mathrm{Y} 7, \mathrm{Y} 13, \mathrm{Y} 14 \mathrm{Y} 18, \mathrm{Y} 5, \mathrm{Y} 9 \\
\mathrm{Y} 16, \mathrm{Y} 17, \mathrm{Y} 19 \mathrm{Y} 15, \mathrm{Y} 21, \mathrm{Y} 6\end{array}$ \\
\hline & Görev alanı dışı işlerle uğraşmak & 5 & $\mathrm{Y} 1, \mathrm{Y} 5, \mathrm{Y} 9, \mathrm{Y} 16 \mathrm{Y} 2$ \\
\hline & Görev dağılımında eşitsizlik & 2 & Y10,Y9 \\
\hline & Görev tanımının açık olmayışı & 2 & Y13,Y18 \\
\hline & Görev dağılımının kişiye uygun olmaması & 1 & Y3 \\
\hline
\end{tabular}

Tablo 2'de görüldüğü gibi müdür yardımcılığından istifa eden öğretmenlerin çoğunluğu idari evrak işlerinin fazla olmasının istifa etmelerinde önemli bir neden olduğunu belirtmişlerdir. $\mathrm{Bu}$ anlamda birçok öğretmenin okul yöneticisi olarak çalıştıkları sürede öğretimsel amaçlarla uğraşmayı hedeflerken, daha çok evrak işleri ile uğraşmaları ve görev alanı dışındaki işler yapmalarının müdür yardımcılığındaki iş doyumlarını olumsuz etkilediği görülmektedir. Konu ile ilgili katılımcılardan biri (Y9) bu durumu şöyle açıklamıştır:

Çok fazla prosedür var, prosedürlerle uğraşmaktan kendi işinizi yapamıyorsunuz. Kağıt işiyle uğraşmak ve sürekli bir yerlere kağıt üzerinden hesap vermekten asıl meselelerle uğraşamadık. İlçenin istediği birçok evrak var. Aklınıza gelebilecek her şeyle uğraşmak zorunda kalmak benim için zordu. Müdürün istediği evrakları arşivleme işlemini yapan bir iş durumuna getirilmiş şuan müdür yardımcılı̆̆ı. Öğrenci işleriyle uğraşmamız gerekirken evrak işleriyle uğraşıyoruz aslında eğitim sistemimiz de böyle ve evrak işlerine dayalı tamamen. Gerçekleri görmüyoruz kağıt üzerinde yaşıyoruz sadece.

İlgili katılımcı (Y9), görüşlerinde evrak işlerinin, görev alanı ile ilgili işlerin büyük bir bölümünü kapladığını ve bu durumun onların öğrenci ve öğretim iş ve işlemlerine yoğunlaşmalarını engellediğini belirtmiştir.

\section{Kariyer Engelleri İle İlgili Nedenler}

Müdür yardımcılığından ayrılan öğretmenlerin kariyer engellerine bağlı nedenlere ilişkin görüşleri Tablo 3'te yer almaktadır. 
Tablo 3

Müdür Yardımcılı̆̆ından Ayrılan Öğretmenlerin Kariyer Engellerine Bağlı Nedenlere İlişkin Görüşleri

\begin{tabular}{|c|c|c|c|}
\hline Temalar & Alt Temalar & Sayı & Katılımcilar \\
\hline \multirow{9}{*}{ 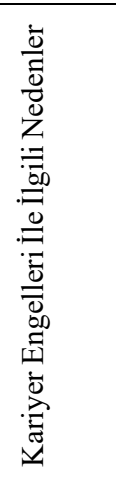 } & Mülakat ve adam kayırma & 15 & $\begin{array}{l}\mathrm{Y} 1, \mathrm{Y} 13, \mathrm{Y} 14, \mathrm{Y} 20, \mathrm{Y} 3, \mathrm{Y} 4, \mathrm{Y} 5 \\
\mathrm{Y} 16, \mathrm{Y} 17, \mathrm{Y} 19, \mathrm{Y} 2, \mathrm{Y} 8, \mathrm{Y} 15, \\
\mathrm{Y} 21, \mathrm{Y} 6\end{array}$ \\
\hline & Kariyer olarak görmeme & 10 & $\begin{array}{l}\text { Y1, Y12, Y14, Y18, Y20, Y3, } \\
\text { Y5, Y16, Y17, Y21 }\end{array}$ \\
\hline & Siyasi-ideolojik engel & 9 & $\begin{array}{l}\text { Y1, Y11, Y13, Y4, Y5, Y16, } \\
\text { Y17, Y2, Y15 }\end{array}$ \\
\hline & Görev süresinin sınırlı olması & 6 & Y20, Y3, Y16, Y19, Y15, Y21 \\
\hline & Atama sisteminin sürekli değişmesi & 5 & Y11, Y16, Y19, Y2, Y21 \\
\hline & Bireysel isteksizlik & 5 & Y7, Y12, Y13, Y18, Y9 \\
\hline & Sendika değiștirme sartı & 4 & Y13, Y17, Y8, Y15 \\
\hline & İleriyi görememek & 4 & Y11, Y17, Y2, Y15 \\
\hline & İşlevsel bir kariyer basamağ1 olmaması & 1 & Y14 \\
\hline
\end{tabular}

Tablo 3’te görüldüğü gibi müdür yardımcılığından istifa eden öğretmenlerin çoğunluğu sözlü sınav ve adam kayırmanın, müdür yardımcılığını bir kariyer olarak görmemelerinin ve siyasi-ideolojik engellerin kendileri açısından ilerlemelerinde engel oluşturduğunu belirtmişlerdir. Bu anlamda eğitim yönetimi açısından nesnel nitelikleri esas alan bir atama ve kariyer sisteminin olmadığı görülmekle birlikte, müdür yardımcılığı görevinin, işin uygulayıcıları tarafından bir kariyer basamağı veya işlevsel bir basamak olarak görülmemesi de dikkate değer nitelik taşımaktadır. Konu ile ilgili katılımcılardan biri (Y16) şu görüşü belirtmiştir:

Eskiden olduğu gibi sınav yok şimdi belli bir yere ait olmak gerekiyor, torpilin olması gerekiyor. Mülakat yapılıyor fakat mülakat objektif olmaz, karşınızdakinin giyim kuşamı dahi etkiler, kaldı ki ülkemizde bu anlamda iyi bir sınav vermemişiz. Mülakat demek ülkemizde adam seçmek demektir, şeffaflık yok. Müdür yardımcısı olarak hayatını devam ettiren insanlar ve emekli olan yüzlerce insan gördüm, çünkü önünde geleceği noktalar okul müdürü, şube müdürü, ilçe veya il müdürü olmak fakat bu kariyerlerin hepsi de bir şekilde başka nitelikler göz önünde bulundurularak doluyor, sonuç olarak müdür yardımcısı, kariyer olarak bu kadroların liyakat dışı nedenlerle doldurulması sonucu yükselemiyor ve emekli olana kadar müdür yardımcısı olarak kalıyor, yapacağı bir şey yok. Şeffaflık yok yani.

İlgili katılımcı (Y16), görüşlerinde müdür yardımcılığı kariyerinde nesnel niteliklerin esas alınmadığını, aidiyet sunan niteliklerin, bu kariyerin ve sonraki kariyer aşamalarının elde edilmesinde etkili olduğunu belirtmiştir. 


\section{Okul Dışı Etkenlerden Kaynaklanan Nedenler}

Müdür yardımcılığından ayrılan öğretmenlerin okul dışı etkenlere bağlı nedenlere ilişkin görüşleri Tablo 4 'te yer almaktadır.

Tablo 4

Müdür Yardımcılı̆̆ından Ayrılan Öğretmenlerin Okul Dışı Etkenlere Bă̆lı Nedenlere İlişkin Görüşleri

\begin{tabular}{llll}
\hline Temalar & Alt Temalar & Sayı & Katılımcılar \\
\hline & Aile & 16 & $\begin{array}{l}\text { Y7, Y1, Y10, Y11, Y12, Y13, Y18, Y20, } \\
\text { Y4, Y5, Y9, Y16, Y17, Y19, Y8, Y21 }\end{array}$ \\
\cline { 2 - 4 } & & 6 & Y12, Y18, Y3, Y4, Y9, Y6 \\
\cline { 2 - 4 } & Olumsuz okul çevresi & 5 & Y7, Y1, Y11, Y13, Y5 \\
\cline { 2 - 4 } & Eve iş getirme & 4 & Y10, Y9, Y16, Y19 \\
\cline { 2 - 4 } & Ulaşım sikıntıs1 & 3 & Y16, Y19, Y6 \\
\cline { 2 - 4 } & Sürekli mevzuat değişiklikleri & 3 & Y14 \\
\cline { 2 - 4 } & Üst yönetimlerin etkisi & 1 & \\
\hline
\end{tabular}

Tablo 4'te görüldüğü gibi müdür yardımcılığından istifa eden öğretmenlerin çoğunluğu aile ve olumsuz okul çevresinin istifa etmelerini önemli düzeyde etkilediğini belirtmişlerdir. Bu anlamda aile, bireyler açısından ertelenemeyecek, vazgeçilemeyecek niteliğiyle ve kariyer hedeflerinin geri plana atılmasını sağlayacak riskler barındırması nedeniyle yaşamsal öneme sahiptir. Konu ile ilgili katılımcılardan birinin (Y21) görüşleri şöyledir:

Aile açısından bırakmayı düşünüyordum. Zaman açısından çok sıkıntı yaşıyordum, sabah yedi akşam yedi gibi çalışıyorduk, ikili eğitim vardı ve aileme yeterli zaman ayıramadım, çocuklarımla yeterince ilgilenemedim. Çocuklar ve eşin, belli bir saatten sonra seni evde görmek istiyorlar, eşim yarım gün çalışıp ben bütün gün okulda olduğum zaman sosyal aktiviteler ister istemez kesintiye uğruyor.

İlgili katılımcı (Y21), görüşlerinde müdür yardımcılığı görevinde uzun çalışma süresinden dolayı ailesine çok fazla zaman ayıramadığını ve bu durumun aile ilişkilerini etkilediğini belirtmiştir.

\section{Okul İçi Etkenlerden Kaynaklanan Nedenler}

Müdür yardımcılığından ayrılan öğretmenlerin okul içi etkenlere bağlı nedenlere ilişkin görüşleri Tablo 5'te yer almaktadır. 
Tablo 5

Müdür Yardımcılı̆̆ından Ayrılan Öğretmenlerin Okul İçi Etkenlere Bağlı Nedenlere Ilişkin Görüşleri

\begin{tabular}{|c|c|c|c|}
\hline Temalar & Alt Temalar & Sayı & Katılımcılar \\
\hline \multirow{11}{*}{ 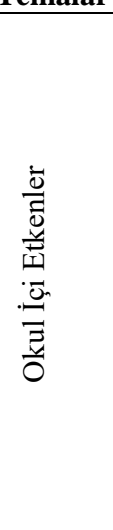 } & İş yoğunluğu (iş yükü) & 19 & $\begin{array}{l}\text { Y7, Y1, Y10, Y11, Y12, Y13, Y14, } \\
\text { Y18, Y3, Y4, Y5, Y9, Y16, Y17, } \\
\text { Y19, Y2, Y8, Y15, Y21 }\end{array}$ \\
\hline & Öğrenci davranış sorunları & 9 & $\begin{array}{l}\text { Y10, Y11, Y12, Y13, Y18, Y5, Y9, } \\
\text { Y19, Y21 }\end{array}$ \\
\hline & Okulun parasal sorunları & 7 & Y1, Y13, Y5, Y19, Y15, Y21, Y6 \\
\hline & Müdürün olumsuz etkisi & 7 & Y12, Y18, Y20, Y4, Y16, Y21, Y6 \\
\hline & Velilerin olumsuz etkisi & 7 & $\mathrm{Y} 1, \mathrm{Y} 10, \mathrm{Y} 11, \mathrm{Y} 18, \mathrm{Y} 3, \mathrm{Y} 5, \mathrm{Y} 17$ \\
\hline & Öğretmenin olumsuz etkisi & 6 & Y1, Y10, Y11, Y18, Y16, Y17 \\
\hline & Personel eksikliği & 6 & $\mathrm{Y} 1, \mathrm{Y} 10, \mathrm{Y} 13, \mathrm{Y} 18, \mathrm{Y} 19, \mathrm{Y} 21$ \\
\hline & Kadro değişimi & 5 & $\mathrm{Y} 18, \mathrm{Y} 5, \mathrm{Y} 16, \mathrm{Y} 2, \mathrm{Y} 21$ \\
\hline & Öğrenci ve öğretmen sayısının fazlalığı & 3 & Y12, Y5, Y17 \\
\hline & Yöneticilerin deneyimsizliği & 1 & $\mathrm{Y} 2$ \\
\hline & Kaynakların etkili yönetilememesi & 1 & Y11 \\
\hline
\end{tabular}

Tablo 5'te görüldüğü gibi müdür yardımcılığından istifa eden öğretmenlerin çoğunluğu iş yoğunluğunun ve iş yükünün bu kariyerden vazgeçmelerinde etkili olduğunu belirtmişlerdir. Bu anlamda bireylerin stres ve tükenmişlik yaşamasında iş yükü önemli bir etken olup birey sınırlarını aşan niteliğe ulaştığında vazgeçme kararlarına neden olan önemli bir etkene dönüşmektedir. Konu ile ilgili katılımcılardan biri (Y15) bu durumu şöyle açıklamıştır: "Ben bulunduğum okulda, bir okulda ne kadar iş varsa hepsi benim üzerimdeydi. Eğitim öğretim işleri, ek dersler yani aklınıza gelebilecek her şey benim üzerimde idi. Nöbetçi olduğumuzda bile iş yoğunluğundan dolayı çıkıp okulu gezemiyorsunuz." diyerek müdür yardımcılığı görevinde çok fazla işle uğraşmak zorunda kaldığını ve bu durumun görevin gerektirdiği rutin akışı bozduğunu belirtmiştir.

\section{Personel İlişkilerinden Kaynaklanan Nedenler}

Müdür yardımcılığından ayrılan öğretmenlerin personel ilişkilerine bağlı nedenlere ilişkin görüşleri Tablo 6'da yer almaktadır.

Tablo 6

Müdür Yardımcllı̆̆ından Ayrllan Öğretmenlerin Personel İlişkilerine Bă̆lı Nedenlere İlişkin Görüşleri

\begin{tabular}{clll}
\hline Temalar & Alt Temalar & Sayı & Katılımcılar \\
\hline & Personele iş yaptırmada zorluk & 7 & Y1, Y12, Y18, Y3, Y5, Y9, Y19 \\
\cline { 2 - 3 } Ödüllendirilmede eksiklik & 6 & Y12, Y13, Y14, Y20, Y9, Y17 \\
\cline { 2 - 3 } Müdürün baskıcı tutumu & 5 & Y12, Y20, Y3, Y13, Y21 \\
\hline
\end{tabular}


Tablo 6 (devam)

\begin{tabular}{|c|c|c|c|}
\hline Temalar & Alt Temalar & Sayı & Katılımcilar \\
\hline \multirow{9}{*}{ 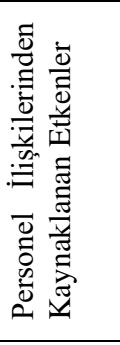 } & Arada kalma & 4 & Y11, Y4, Y5, Y2 \\
\hline & Müdürün yetersizliği & 4 & Y14, Y20, Y16, Y6 \\
\hline & Müdürün ayrımcılık yapması & 3 & Y4, Y16, Y6 \\
\hline & Fikirlerin önemsenmemesi & 3 & $\mathrm{Y} 14, \mathrm{Y} 18, \mathrm{Y} 3$ \\
\hline & Görüş farklılıkları & 3 & Y11, Y20, Y5 \\
\hline & Müdürün, konumunun sarsıldığı düşüncesi & 3 & Y4, Y16, Y21 \\
\hline & Yöneticiler arası çatışma & 2 & Y13, Y20 \\
\hline & Karar süreçlerine dahil edilmeme & 2 & Y11, Y15 \\
\hline & İlişki mesafesini ayarlamada eksiklik & 1 & Y18 \\
\hline
\end{tabular}

Tablo 6'da görüldüğü gibi müdür yardımcılığından istifa eden öğretmenlerin çoğunluğu, özelikle 1-3 yıl bu görevi yapıp istifa edenler, öğretmenlere ve diğer personele iş yaptırmada zorluk yaşadıklarını, müdür tarafından ödüllendirilmede eksiklik yaşadıklarını ve müdürün baskıcı tutuma sahip olduğunu belirtmişlerdir. Bu anlamda mesleğe yeni başlayan müdür yardımcılarının deneyim eksikliğinden kaynaklanan olumsuzluklar yaşamaları olasıdır. Bu durum, yöneticilik kıdemi düşük olan müdür yardımcılarının özellikle öğretmen, müdür ve diğer personel ile ilişkilerini ayarlamada bazı sorunlar yaşamaları, kariyerlerinin başlangıç aşamasındaki idealist beklentilerinin ortamdaki diğer paydaşlarla çatışması ve ilişkilerin bozulmasına neden olacak niteliğe ulaşması ile açıklanabilir.

Konu ile ilgili katılımcılardan biri (Y12) "Yine hizmetlilerin iş ve işlemlerini takip ettiğim için onlara iş yaptırma konusunda da zorluk yaşadım. Hatta birinin işine son vermek zorunda kaldım. Bu da çok üzmüştü beni” diyerek personele iş yaptırmada zorluk yaşadığını, bir diğer katılımcı ise (Y14) "Bir keresinde bir öğrencinin il düzeyinde kompozisyon dalında birinci olmasına rehberlik düzeyinde katkı sundum. Sonrasında bu başarının diğer bir müdür yardımcısının başarı belgesi almasında kullanıldığını öğrendim" diyerek ödüllendirme konusunda haksızlık ve eşitsizliklerin olduğunu belirtmiştir.

\section{Haklar ve Sorumluluklar Bağlamında Nedenler}

Müdür yardımcılığından ayrılan öğretmenlerin müdür yardımcılarının hakları ve sorumlulukları bağlamındaki nedenlere ilişkin görüşleri Tablo 7'de yer almaktadır. 
Tablo 7

Müdür Yardımcılı̆̆ından Ayrılan Öğretmenlerin Müdür Yardımcılarının Haklarl ve Sorumlulukları Bă̆lamındaki Nedenlere İlişkin Görüşleri

\begin{tabular}{|c|c|c|c|}
\hline Temalar & Alt Temalar & Sayı & Katılımcılar \\
\hline \multirow{6}{*}{ 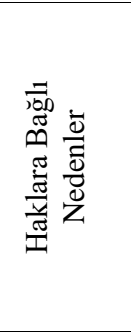 } & Maddi getirisinin az olması & 15 & $\begin{array}{l}\mathrm{Y} 7, \mathrm{Y} 11, \mathrm{Y} 12, \mathrm{Y} 13, \mathrm{Y} 14, \mathrm{Y} 18, \mathrm{Y} 3, \mathrm{Y} 5 \\
\mathrm{Y} 9, \mathrm{Y} 16, \mathrm{Y} 17, \mathrm{Y} 19, \mathrm{Y} 8, \mathrm{Y} 15, \mathrm{Y} 21\end{array}$ \\
\hline & İzinlerin azlığı ve kullanamama & 14 & $\begin{array}{l}\text { Y7, Y1, Y11, Y12, Y13, Y18, Y3, Y4, } \\
\text { Y5, Y9, Y16, Y19, Y8, Y21 }\end{array}$ \\
\hline & Uzun çalışma süresi & 14 & $\begin{array}{l}\text { Y7, Y11, Y12, Y13, Y14, Y18, Y3, Y5, } \\
\text { Y16, Y17, Y19, Y8, Y15, Y6 }\end{array}$ \\
\hline & Yaptırım (yetki) gücünün olmayışı & 7 & Y12, Y18, Y5, Y16, Y17, Y19, Y21 \\
\hline & Ders yükünün fazla olmas1 & 2 & Y1, Y18 \\
\hline & İnsiyatif kullanamama & 2 & Y4, Y5 \\
\hline \multirow{4}{*}{ 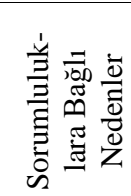 } & Her şeyden sorumlu olma & 13 & $\begin{array}{l}\mathrm{Y} 7, \mathrm{Y} 1, \mathrm{Y} 12, \mathrm{Y} 18, \mathrm{Y} 3, \mathrm{Y} 5, \mathrm{Y} 9, \mathrm{Y} 16, \\
\mathrm{Y} 17, \mathrm{Y} 19, \mathrm{Y} 2, \mathrm{Y} 15, \mathrm{Y} 21\end{array}$ \\
\hline & Hata ve yanlışlardan sorumlu kalma & 5 & Y12, Y4, Y5, Y15, Y21 \\
\hline & Sorumlulukların eşit dağıtılmaması & 3 & Y10, Y3, Y9 \\
\hline & Süresiz sorumluluk & 2 & Y7, Y16 \\
\hline
\end{tabular}

Tablo 7'de görüldüğü gibi müdür yardımcılığından istifa eden öğretmenlerin çoğunluğu, müdür yardımcılığının maddi getirisinin ve izinlerinin az olduğunu, izin kullanamadıklarını, uzun çalışma sürelerine sahip olduklarını, buna karşın her şeyden sorumlu kaldıklarını ve sorumluluk yüklerinin süresiz ve ağır olduğunu belirtmişlerdir. $\mathrm{Bu}$ anlamda müdür yardımcılığı görevi, her ne kadar okul içerisinde bir kariyer gibi görünse de yaklaşık olarak öğretmenlerle aynı maddi getiriye sahip, buna karşın sorumluluğun, mesainin ve iş yükünün fazla olduğu bir nitelik taşımaktadır. Mesai saatleri dışında okulda işlere devam etme, eve iş getirme, hafta sonu çalışma gibi iş yüklerini barındıran ve son yıllarda birim iş oranının giderek arttığı okul yöneticiliğinin, müdür yardımcıları açısından ayrılma kararını kolaylaştıran ve buna isteklendiren bir niteliğe bürünmesi olasıdır.

Konu ile ilgili katılımcılardan biri (Y8) "Belki de daha fazla çalışabilirdim, ama işte çok fazla zaman ayırıp az ücret alınca bırakmam gerektiğini düşündüm. Ücreti düşük, öğretmenden farkı yok hatta öğretmen senden daha fazla alabiliyor ve daha fazla zaman harcıyorsun" diyerek müdür yardımcılığı görevinde maddi olarak doyum sağlayamadığını ve iş-ücret dengesinin görevi bırakmasında etkili olduğunu; bir diğer katılımcı (Y13) "Kar yağıyor herkes tatil yapıyor sen okuldasın, hafta sonu çalışmak zorunda kalıyorsun" diyerek izin haklarının yetersiz ve adil olmadığını; başka bir katılımcı ise (Y21) "Müdür yardımcısı iken bir öğretmenimiz, 'hocam bilgisayarımda virüs var, halledebilir misiniz' dediğini hatırlıyorum, o açıdan müdür yardımcılarına acıyorum yükleri çok ağır, her şeyden sorumlular" diyerek sorumluluk alanlarının çok yoğun ve fazla olduğunu belirtmiştir. 


\section{Bireysel Nedenler}

Müdür yardımcılığından ayrılan öğretmenlerin bireysel nedenlere ilişkin görüşleri Tablo 8'de yer almaktadır.

Tablo 8

Müdür Yardımcılı̆̆ından Ayrılan Öğretmenlerin Bireysel Nedenlere İlişkin Görüşleri Temalar Alt Temalar Sayı Katılımcılar

\begin{tabular}{|c|c|c|c|}
\hline \multirow{9}{*}{ 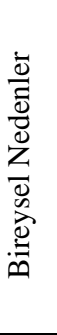 } & Zihinsel-duygusal tükenme & 8 & $\mathrm{Y} 11, \mathrm{Y} 12, \mathrm{Y} 14, \mathrm{Y} 18, \mathrm{Y} 20, \mathrm{Y9}, \mathrm{Y} 17, \mathrm{Y} 19$ \\
\hline & Kendine zaman ayıramama & 5 & Y1, Y10, Y18, Y9, Y8 \\
\hline & Umutsuzluk & 3 & Y1, Y3, Y4 \\
\hline & İş doyumunun azalması & 2 & Y18, Y17 \\
\hline & Yetersizlik hissetme & 2 & Y13, Y5 \\
\hline & Çatışmadan kaçınma & 2 & $\mathrm{Y} 14, \mathrm{Y} 2$ \\
\hline & Motivasyonda azalma & 1 & Y14 \\
\hline & Okula uyum sorunu & 1 & Y13 \\
\hline & Beklentilerle ortamın uyumsuzluğu & 1 & Y3 \\
\hline
\end{tabular}

Tablo 8'de görüldüğü gibi müdür yardımcılığından istifa eden öğretmenlerin çoğunluğu zihinsel-duygusal tükenmişlik yaşadıklarını ve kendilerine yeterince zaman ayıramadıklarını belirtmişlerdir. Psikolojik etkenler önemli kararların alınmasında temel zemini oluşturmaktadır. $\mathrm{Bu}$ anlamda okul bağlamında yaşanan olumsuzluklar veya okul dışı bireyi tetikleyen baskı kaynakları öncelikli olarak okul yöneticilerinin ruhsal dünyasını zedelemektedir. Psikolojik anlamda yaşanan tükenmişlik, umutsuzluk, düşük güdülenme, doyumun azalması, müdür yardımcıları açısından rahatlayabileceği ve mutluluğu aradığı bir mesleki değişim kararı almasına neden olabilmektedir.

Konu ile ilgili katılımcılardan biri (Y20) "Müdür yardımcısıyken daha yorgun hissediyordum kendimi ve sürekli yorgun düşüyordum veya aklınız rahat değil sürekli zihniniz meşgul ama öğretmenlikte öyle değil daha rahatsınız bu konuda" diyerek müdür yardımcılığı görevinde bedensel ve ruhsal olarak tükenmişlik yaşadığını; bir diğer katılımcı ise (Y8) "Ben daha çok zaman anlamında, kendime, aileme daha fazla zaman ayırayım diye ayrıldım" diyerek kendi bireysel gereksinimlerine ve ailesine zaman ayırmanın etkili olduğunu belirtmiştir.

\section{Ayrılmaya İsteklendiren Kaynaklar}

Müdür yardımcılığından ayrılan öğretmenlerin kendilerini ayrılmaya isteklendiren kaynaklara ilişkin görüşleri Tablo 9'da yer almaktadır. 
Tablo 9

Müdür Yardımcılı̆̆ından Ayrılan Öğretmenlerin Kendilerini Ayrllmaya İsteklendiren Kaynaklara İlişkin Görüşleri

\begin{tabular}{llll}
\hline Temalar & Alt Temalar & Sayı & Katılımcılar \\
\hline \multirow{2}{*}{$\begin{array}{l}\text { Ayrılmaya } \\
\text { İsteklendiren } \\
\text { Kaynaklar }\end{array}$} & Bireysel karar & 10 & Y11,Y12,Y13,Y14,Y18,Y20,Y9Y16,Y17,Y6 \\
\cline { 2 - 4 } & Arkadaş çevresi & 8 & Y1,Y10,Y18,Y4,Y5,Y19,Y8,Y21 \\
\cline { 2 - 4 } & Aile bireyleri & 7 & $\mathrm{Y} 7, \mathrm{Y} 1, \mathrm{Y} 12, \mathrm{Y} 4, \mathrm{Y} 8, \mathrm{Y} 15, \mathrm{Y} 21$ \\
\cline { 2 - 4 } & Meslektaş etkileşimi & 1 & $\mathrm{Y} 3$ \\
\hline
\end{tabular}

Tablo 9'da görüldüğü gibi müdür yardımcılığından istifa eden öğretmenler, istifa etme süreçlerinde bireysel kararlarının, arkadaş çevresi ve aile bireylerinin etkili olduğunu belirtmişlerdir. $\mathrm{Bu}$ anlamda bireyin gelecek planlamalarında bir karara varması birey yaşamında olası değişimleri sağlamaktadır. Bireye yakın olan aile ve arkadaş çevresinin baskı ve ikna unsuru olarak birey kararında etkili olması dikkate değerdir. Konu ile ilgili katılımcılardan biri (Y20) "Müdür yardımcılığı görevimden kendi isteğim ile ayrıldım, bu konuda beni kimse ikna etmedi, yapmak istemediğime karar verip istifa ettim" diyerek iç güdülenme süreçlerinin etkili olduğunu; bir diğer katılımcı ise (Y8) “Arkadaşlarım da yine gereksiz, çok fazla çalışıyorsun kar tatili yok maaş farkı yok, şeklinde telkinlerde bulunuyorlardı. Bayan işi değil yani” diyerek dış ikna öğelerinin etkili olduğunu belirtmiştir.

\section{Öğretmenliğe Dönüş Sonrası Yaşanan Değişiklikler}

Müdür yardımcılığından ayrılan katılımcıların öğretmenliğe dönüş sonrası yaşadıkları olumlu ve olumsuz değişikliklere ilişkin görüşleri Tablo 10 ' da yer almaktadır.

Tablo 10

Müdür Yardımcılı̆̆ından Ayrılan Katılımclların Öğretmenliğe Dönüş Sonrası Yaşadıklarl Olumlu ve Olumsuz Değişikliklere Illişkin Görüşleri

\begin{tabular}{|c|c|c|c|}
\hline Temalar & Alt Temalar & Sayı & Katılımcılar \\
\hline \multirow{12}{*}{ 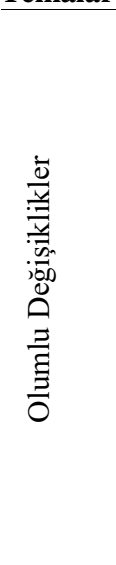 } & Rahatlama-mutluluk & 12 & $\begin{array}{l}\text { Y7, Y1, Y13, Y18, Y20, Y16, Y17, } \\
\text { Y19, Y8, Y15, Y21, Y6 }\end{array}$ \\
\hline & Sorumlulukta azalma & 10 & $\begin{array}{l}\mathrm{Y} 7, \mathrm{Y} 1, \mathrm{Y} 11, \mathrm{Y} 18, \mathrm{Y} 5, \mathrm{Y} 16, \mathrm{Y} 19 \\
\mathrm{Y} 15, \mathrm{Y} 21, \mathrm{Y} 6\end{array}$ \\
\hline & Aileye daha fazla zaman ayırma & 9 & $\begin{array}{l}\text { Y7, Y12, Y18, Y4, Y16, Y19, Y15, } \\
\text { Y21, Y6 }\end{array}$ \\
\hline & Kendisine zaman ayırma & 7 & Y10, Y11, Y18, Y5, Y9, Y19, Y15 \\
\hline & Öğrencilerle buluşma mutluluğu & 7 & $\mathrm{Y} 11, \mathrm{Y} 12, \mathrm{Y} 13, \mathrm{Y} 14, \mathrm{Y} 20, \mathrm{Y} 9, \mathrm{Y} 2$ \\
\hline & Bakış açısında değişme & 6 & Y13, Y14, Y18, Y4, Y17, Y2 \\
\hline & Kişisel gelişime zaman ayırma & 4 & Y10, Y11, Y18, Y3 \\
\hline & İş doyumu & 4 & $\mathrm{Y} 12, \mathrm{Y} 18, \mathrm{Y} 20, \mathrm{Y} 17$ \\
\hline & Eski rolün uyumu kolaylaştırması & 3 & Y18, Y4, Y8 \\
\hline & Stres ve kaygının azalması & 3 & Y10, Y19, Y6 \\
\hline & Sınıf içerisinde bağımsız hareket alanı & 1 & Y14 \\
\hline & Maddi iyileşme & 1 & Y16 \\
\hline
\end{tabular}


Tablo 10 (devam)

\begin{tabular}{|c|c|c|c|}
\hline \multicolumn{2}{|c|}{ Temalar Alt Temalar } & \multicolumn{2}{|c|}{ Sayı Katılımcılar } \\
\hline \multirow{7}{*}{ 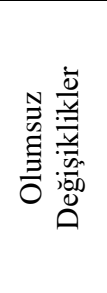 } & Olumsuzluk olmadı & 10 & $\begin{array}{l}\text { Y7, Y11, Y13, Y14, Y18, Y3, Y5, } \\
\text { Y17, Y8, Y15 }\end{array}$ \\
\hline & Uyum sorunu & 4 & $\mathrm{Y} 12, \mathrm{Y} 4, \mathrm{Y} 19, \mathrm{Y} 21$ \\
\hline & Rol değişikliğinde zorluk yaşama & 3 & $\mathrm{Y} 12, \mathrm{Y} 4, \mathrm{Y} 19$ \\
\hline & Hareket alanının daralması & 2 & Y12, Y6 \\
\hline & Sınıf yönetiminde eksiklik yaşama & 2 & $\mathrm{Y9}, \mathrm{Y} 2$ \\
\hline & Prestij kayb1 & 1 & Y19 \\
\hline & Cevrenin yetersiz görme algısı & 1 & Y16 \\
\hline
\end{tabular}

Tablo 10’da görüldüğü gibi müdür yardımcılığından istifa eden öğretmenlerin çoğunluğu, dönüş sonrası rahatlama-mutluluk yaşadıklarını, sorumluluklarının azaldığını, aileye ve kendilerine daha fazla zaman ayırdıklarını ve öğrencilerle tekrar buluşmanın onları mutlu ettiğini belirtmişlerdir. Aynı zamanda çoğunluğu öğretmenliğe dönüş sonrası herhangi bir olumsuzluk yaşamadıklarını belirtmişlerdir. $\mathrm{Bu}$ anlamda yoğun bir işle uğraşmak zorunda kalan ve stres, tükenmişlik yaşayan müdür yardımcılarının öğretmenliğe dönüş sonrası mutluluklarını belirtmeleri, istifa etme nedenlerinin dikkate alınması ve ayrıntılı incelenerek gerekli çalışmaların yapılması bakımından dikkate değerdir.

Katılımcılardan biri (Y7) "Olumlu olarak kafam çok rahatladı, eve gittiğimde kafam rahat, okulla ilgili bir şey düşünmüyorum” diyerek ruhsal olarak doyum düzeyinin yükseldiğini; bir diğer katılımcı (Y19) "Sınıftaki sorumlulukla okulun sorumluluğu aynı değil, sınıfta 40 öğrenci ile muhatapken idarecilikte 2000 öğrenci ve bunların velileri ile aynı zamanda 50-60 öğretmenle muhatap oluyorsun. Yorucu yani. Okulun tüm sorumluluğundan ziyade sınıfın sorumluluğu daha az" diyerek öğretmenliğe dönüş sonrası sorumluluklarının azaldığını; bir diğer katılımcı ise (Y17) "Olumsuz anlamda hiçbir şey yaşamadım döndükten sonra, sanki altı yıl önce nerde bıraktıysam oradan devam etmişim gibi hissediyorum" diyerek öğretmenliğe dönüş sonrası öğretmenlik yaşamını etkileyen herhangi bir olumsuzluk yaşamadığını belirtmiştir.

\section{Müdür Yardımcılığına Geri Dönme Durumu}

Müdür yardımcılığından ayrılan öğretmenlerin tekrar müdür yardımcılığına geri dönme durumuna ilişkin görüşleri Tablo 11'de yer almaktadır.

Tablo 11

Müdür Yardımcılı̆̆ından Ayrılan Öğretmenlerin Tekrar Müdür Yardımcılı̆̆ına Geri Dönme Durumuna İlişkin Görüşleri

\begin{tabular}{|c|c|c|c|}
\hline Temalar & Alt Temalar & Sayı & Katılımcilar \\
\hline Ger & Düşünmüyorum & 12 & $\mathrm{Y} 7, \mathrm{Y} 1, \mathrm{Y} 11, \mathrm{Y} 14, \mathrm{Y} 20, \mathrm{Y} 9, \mathrm{Y} 16, \mathrm{Y} 17, \mathrm{Y} 2, \mathrm{Y} 8, \mathrm{Y} 15, \mathrm{Y} 6$ \\
\hline Durumu & Düşünüyorum & 9 & $\mathrm{Y} 10, \mathrm{Y} 12, \mathrm{Y} 13, \mathrm{Y} 18, \mathrm{Y} 3, \mathrm{Y} 4, \mathrm{Y} 5, \mathrm{Y} 19, \mathrm{Y} 21$ \\
\hline
\end{tabular}


Tablo 11'de görüldüğü gibi müdür yardımcılığından istifa eden öğretmenlerin çoğunluğu, müdür yardımcılığına geri dönmeyi düşünmemektedirler. Bu anlamda verdikleri kararın onları mutlu ettiği ve güdülediği görülmektedir. Fakat birçoğu müdür yardımcılığına geri dönme durumuyla ilgili olarak açık kapı bırakmakta ve çeşitli beklentileri şart koşmaktadır. Konu ile ilgili katılımcılardan biri (Y7) "Asla dönmeyi düşünmüyorum. Dönersem, beklentilerim ise müdür yardımcılarının maaşının ve ek dersinin arttırılması, idarecilerin derse girme olayının kaldırılması, ek derslerin izin durumlarında kesilmemesi, bunlar olursa belki dönebilirim" diyerek kararlı bir görüş sunmuş ve dönme isteği olduğunda ise haklara dönük çeşitli beklentiler dile getirmiştir.

\section{Tartışma, Sonuç ve Öneriler}

Araştırmada çalışma grubunu oluşturan katılımcıların büyük çoğunluğu (12 / 21) kariyerlerinin başlangıç basamağında (1-3 yıl) istifa etmişlerdir. Bu durum Bakioğlu'nun (1994) araştırmasıyla paralellik göstermektedir. Fakat, Darmody ve Smyth'e (2008) göre okul yöneticilerinin, kariyere başladıkları ilk yıllarda iş doyumları yükselirken özellikle 4-6 yıllık dönemde iş doyumlarında düşüş yaşanmakta ve daha sonra yöneticilik kıdemleri arttıkça iş doyumları artmaktadır. Bu anlamda araştırmamız ile farklılık göstermektedir. Ancak istifa edenlerde ikinci sırayı (5 / 21) 4-8 yıllık yöneticilik kıdemi aralığında istifa edenler almakta olup bu anlamda Darmody ve Smyth'in (2008) araştırmasındaki iş doyumunun zayıfladığı dönem (4-6 yıl yönetici kıdem aralığı) ile paralellik göstermektedir. Yine bu araştırmada istifa edenler arasında yöneticilik deneyim yılı yüksek olanların az olması Darmody ve Smyth'in (2008) kariyer ilerledikçe iş doyumunun artmasıyla açıklanabilir. Aynı zamanda Amerika'da RAND adlı şirket tarafından yapılan bir araştırmada da birçok okul yöneticisinin mesleğinin ilk veya ikinci yılında ayrıldıkları bulgulanmıştır. Hatta katılımcıların yüzde ellisinden daha fazlası mesleğin ilk iki yılında yöneticilik görevinden ayrılmışlardır (Burkhauser ve diğ., 2012). Okul yöneticiliğinin ilk yıllarının görevden ayrılma kritik kararına zorlayan rol karmaşası süreci, okul yöneticilerinin kariyer aşamalarının belirlenmesine yönelik yapılan araştırma ve çalışmalarda da göze çarpmaktadır (Hart, 1993; Reeves ve diğ., 1998; Weindling, 2000). Bu durum, müdür yardımcılığının ilk yıllarının zorlu sürecinin, ayrılma nedenlerine ilişkin kaynağ 1 oluşturduğunu göstermektedir.

Müdür yardımcılığından istifa eden öğretmenlerin büyük çoğunluğu, müdür yardımcılı̆̆ 1 yaparken idari evrak işlerinin fazla olduğunu belirtmişlerdir. Aynı zamanda görev alanı dışı işlerle uğraştıklarını, görev dağılımında eşitsizlik olduğunu, görev tanımlarının açık olmadığını ve kendilerine uygun olmadığını belirtmişlerdir. Bu bağlamda Murphy’e (1995) göre işyerlerinde rol çatışmasını oluşturan temel öğelerden biri, bireyin kurumdaki rolü, rol belirsizliği, personelin sorumluluğu, tanımlanmamış örgütsel sınırlar nedeniyle meydana gelen çatışmalardır (akt., Manabete, John, Makinde ve Duwa, 2016). Gmelch ve Swent'e (1982) göre okul yöneticileri, gündelik idari işlerin yerine getirilmesinden kaynaklanan stres yaşamaktadırlar (akt., Gmelch, Gates, Parkay ve Torelli, 1994). Koşar, Sezgin ve 
Aslan (2013), okul yöneticilerinin görev alanları dışında birçok işle ilgilenmek zorunda kaldıklarını belirlemiştir. Turan ve Yalçın (2015) ise okul yöneticilerinin yapmak istedikleri işler ile yaptıkları işler arasında anlamlı bir farklılığın olduğunu ve bu durumun okul yöneticisinin asli görevinden uzaklaşmasına neden olduğunu saptamıştır. Bu anlamda elde edilen bulgular diğer araştırma sonuçlarıyla paralellik göstermektedir.

Müdür yardımcılığından istifa eden öğretmenlerin büyük çoğunluğu, önlerinde kariyer engeli olarak sözlü sınav (mülakat), adam kayırma olduğunu ve müdür yardımcılığını kariyer olarak görmediklerini belirtirken siyasi-ideolojik engellerin olduğunu da dile getirmişlerdir. Aynı zamanda görev süresinin sınırlı olmasının, atama sisteminin sıklıkla değişmesinin, sendika değiştirmek zorunda kalmalarının ve ileriyi görememelerinin müdür yardımcılığı kariyeri önünde bir engel olduğunu belirtmişlerdir. Bu bağlamda Erginer ve Köse'ye (2012) göre siyasi kadrolaşma ve kuralsız atamalar, Shen, Cooley ve Ruhl-Smith'e (1999, s. 359) göre ise ilerleme şansı olmaması okul yöneticilerinin mesleği bırakmalarında etkili olmaktadır. Yine Murphy'e (1995) göre bireylerin işyerinde yaşadıkları stresi yaratan kaynaklardan biri de, bireylerin kariyer gelişimi doğrultusunda yükselme veya yükselmeme, iş güvenliğinin eksikliğidir (akt., Manabete ve diğ., 2016). Aynı zamanda Türkmenoğlu ve Bülbül (2015) de okul yöneticilerinin dört yıllığına görevlendirilmesinin, okul kültürü oluşturma açısından yetersiz kalacağını, yöneticiliğe atanan kişilerin görev süresi bittikten sonra tekrar görevlendirilme yönünde kaygılar taşıyacaklarını, güdülenmelerinin ve okula bağlılıklarının azalacağını, mülakata dayalı bir atama sisteminin, nesnel olmayan, kayırmaya yönelik taraflı değerlendirmelere yol açacağını belirtmiş̧lerdir. Bu yönüyle elde edilen bulgular diğer araştırma sonuçlarıyla desteklenmektedir.

Yine büyük çoğunluğu, müdür yardımcılığından istifa etmelerinde dış etken olarak aileden kaynaklanan nedenlerin etkili olduğunu belirtmişlerdir. Bu bağlamda, Shen ve diğ.'ne (1999) göre aile ve toplum ile ilişkili sorunlar okul yöneticilerinin mesleği bırakmalarında etkili olmaktadır. Aileden kaynaklanan etkenlerin, özellikle kadın yöneticiler tarafından ertelenemeyecek risk (çocuğun bakımı, aile bütünlüğü gibi) öğeleri barındırması nedeniyle bireylerde kariyerden vazgeçmeye uzanan baskın etken olabileceği düşünülmektedir.

Katılımcıların büyük çoğunluğu, müdür yardımcılığından istifa etmelerinde okul içi etken olarak iş yoğunluğunun ve iş yükünün etkili olduğunu belirtmişlerdir. Bununla birlikte ögrenci davranış sorunlarının, okulun parasal yetersizliklerinin, müdürün, velilerin ve öğretmenlerin olumsuz etkisinin de etkili olduğunu dile getirmişlerdir. Ayrıca personel eksikliğinin, sürekli kadro değişiminin, öğrenci ve ögretmen sayısının fazla olmasının, yöneticilerin deneyimsizliğinin etkisinden de söz edilmiştir. Bu bağlamda, Göksoy (2015), okulların, en az bürokrasinin görüleceği yerler olarak bilinirken tam tersine özellikle sıkı hiyerarşi, evrak işi, iş yükü, işlemlerin yavaş işlemesi gibi süreçlerin yoğun olarak hissedildiği yerler olduğunu belirtmektedir. Yine Gmelch ve Swent (1982), okul yöneticilerinin, okul bütçesine 
halkın desteğini sağlama kaynaklı ve öğrenciler arasındaki çatışmaları ele alma, aile ve okul çatışmasını çözme, öğrenci disiplin sorunlarını ele alma gibi çatışma ortamlarının yarattığı stres durumlarını yaşadığını (akt., Gmelch ve diğ., 1994); Jonga, Grundmeyer ve Yankey (2017), yöneticilerin yüksek iş istemleri ve mantıksız beklentiler, paydaşları yönetme zorlukları, sorunlu iş-yaşam dengesi, desteğin azlığı nedenlerinden dolayı iş memnuniyetsizliği yaşadıklarını; Allen ve Weaver (2014), okul müdür yardımcılarının daha çok finans-bütçe, zaman yönetimi, iş yaşam dengesi, okul kültürü gibi alanlarda gelişmeye gereksinim duyduklarını; Shoho ve Barnett (2010) yeni okul yöneticilerini zorlayan en önemli öğelerden birinin okul bütçesiyle baş etmek ve artan iş yükü olduğunu; Gray ve Behan (2005), okul yöneticilerinin özellikle belirli branşlarda öğretmen bulmakta zorlandıklarını ve bunları geçici personelle çözmeye çalıştıklarını ve bu durumun okul açısından sorunlar yarattı̆̆ını; Hausman ve diğg. (2001) ise müdür yardımcılarının çoğunluğunun, zamanlarını daha çok öğrenci sorunlarını çözmek ve öğrenciyle ilgili olarak aile ve öğretmenlerle iletişim kurmak için harcamakta olduklarını belirlemişlerdir. Bu yönüyle elde edilen bulgular diğer araştırma sonuçları ile paralellik göstermektedir.

Araştırmada, müdür yardımcılığından istifa eden öğretmenlerin büyük çoğunluğu öğretmenlere ve diğer personele iş yaptırmakta zorluk yaşadıklarını belirtmişlerdir. Aynı zamanda müdürün kendilerini ödüllendirmesinde eksiklik yaşadıklarını, müdürün baskıcı tutumunun olduğunu ve öğretmen ile müdür arasında kaldıklarını belirtmişlerdir. Yine okul müdürlerinin yetersiz olduğunu, ayrımcılık yaptığını ve zaman zaman müdür yardımcılarına daha fazla ilgi gösterilmesi nedeniyle kendi konumlarının sarsıldığı düşüncesine kapıldıklarını belirtmişlerdir. Aynı zamanda müdür tarafından düşüncelerinin önemsenmediğini, müdür ile görüş farklılıklarına sahip olduklarını ve zaman zaman yöneticiler arası çatışma yaşandığını, okuldaki karar süreçlerine dâhil edilmediklerini, öğretmen ve diğer personelle ilişki mesafelerini ayarlamalarında eksiklik yaşadıklarını belirtmişlerdir. Özellikle 1-3 kıdem aralığında istifa edenlerin daha fazla görüş bildirmesi, yöneticilik kariyerinde yeni olan bu evredeki yöneticilerin öğretmen ve diğer personelle ilişkiyi ayarlamada ve yönetmede deneyimsiz olduklarının ve sorun yaşadıklarının göstergesidir. $\mathrm{Bu}$ bağlamda, Murphy (1995), bireylerin işyerinde yaşadıkları stresi oluşturan temel kaynakları, meslektaşları ve astları ile düşük düzeyde ilişki kurmak, şiddet ve taciz tehdidi, karar vermede katılımc1 veya katılımcı olmayan kurumsal yapı olarak belirtmiştir (akt., Manabete ve diğ. 2016). Yine Hayon, Faraj ve Wubbels (2001), yöneticilerde kişiler arası ilişki algılamalarının olumlu olmasının tükenmişliği azaltacağını, olumsuz olmasının ise tükenmişliği arttıracağını belirtmektedir. Erginer ve Köse (2012) ise okul yöneticilerinin çalışmalarının değer görmemesinin onların görevi bırakmalarına neden olacağını vurgulamıştır.

Bununla birlikte müdür yardımcıllğından istifa eden öğretmenlerin büyük çoğunluğu, bu görevin ekonomik anlamda herhangi bir maddi getirisinin olmadığını, müdür yardımcılarının izin haklarının az olduğunu ve çoğu zaman kullanamadıklarını öne sürmüşlerdir. Yine uzun çalışma sürelerine sahip olduklarını dile getirmişlerdir. Aynı zamanda yaptırım (yetki) güçlerinin olmadığını, okulda boş derslere ve maaş 
karşılığı derslere girmeleri nedeniyle ders yüklerinin fazla olduğunu ve okulda insiyatif kullanamadıklarını belirtmişlerdir. Bu bağlamda, Shen ve diğ. (1999), maaş düşüklüğünün okul yöneticilerinin mesleği bırakmalarında etkili olduğunu; Dlugosh (1994), okul yöneticilerinin, maaşlarını arttırmak ve üst pozisyonlara yükselmek nedenlerinden dolayı meslekte hareketlilik yaşadıklarını; Kruger, Eck ve Vermeulen (2005) ise okul yöneticilerinin \% 70'inin işlerinin yapısının değiştiğini kabul ettiklerini ve çalışma koşullarının yaşadıkları bunalımlarda önemli bir etken olduğunu belirlemiştir. $\mathrm{Bu}$ yönüyle elde edilen bulgular diğer araştırma sonuçlarıyla da desteklenmektedir.

Araştırmada katılımcıların büyük çoğunluğu okuldaki her şeyden sorumlu olduklarını belirtmişlerdir. Aynı zamanda, müdür tarafından verilen sorumlulukların eşit dağıtılmadığını, okulda her ay düzenli yapılması gereken işler olduğu için sürekli sorumluluk altında kaldıklarını belirtmişlerdir. Amerika'da da 2012'de 500 okul yöneticisi üzerinde yapılan bir araştırmada kamu okullarındaki yöneticilerin, yaklaşık $\%$ 75'i işlerinin çok karmaşık olduğunu ve \% 48'i hafta içerisinde belirli günlerde kendilerini yoğun stres altında hissettiklerini, onda dokuzu ise öğrencileriyle ilgili olarak meydana gelen her şeyden kendilerini sorumlu hissettiklerini belirtmişlerdir (MetLife Survey, 2012 akt., Jonga ve diğ., 2017). Bu anlamda bu araştırma, elde edilen bulguları destekler niteliktedir.

Müdür yardımcılığından istifa eden öğretmenlerin büyük çoğunluğu, müdür yardımcılığı görevinde zihinsel-duygusal tükenme yaşadıklarını belirtmiştir. Aynı zamanda müdür yardımcılığı görevinde kendilerine zaman ayıramadıklarını, kendilerini umutsuz ve yetersiz hissettiklerini, isteklerinin azaldığını öne sürmüşlerdir. Yine okula uyum sorunu yaşadıklarını, beklentileriyle ortamın uygun olmadığını, iş doyumlarının azaldığını ve çatışmadan kaçınmak amacıyla istifa ettiklerini vurgulamışlardır. Bireysel neden belirtenlerin büyük çoğunluğu (1-3 yıl) yönetici deneyim aralığında istifa etmişlerdir. Bu durum yöneticiliğin ilk yıllarında müdür yardımcılarının işi öğrenme ve işe uyum sürecinde olmaları sebebiyle çevresindeki en ufak baskıya karşı duyarlı olmaları ve yetersizlik duygusu temelinde vazgeçme psikolojisinin galip gelmesi ile açıklanabilir. Yapılan araştırmalar da bu araştırmanın bulgularını destekler niteliktedir. Örneğin Amerika'da okul yöneticileriyle yapılan bir araştırmada kamu okullarındaki yöneticilerin iş memnuniyetlerinin beş yıldan daha az bir sürede yüzde dokuz oranında azaldığ bulgulanmıştır (MetLife Survey, 2012 akt., Jonga ve diğ., 2017). Bakioğlu'na (1994) göre başlangıç evresinde yöneticiler, rollerin çeşitliliği nedeniyle şaşkınlık yaşamakta, zorlanmakta ve bu dönem zorlu geçen dönem olarak nitelendirilmektedir. Manabete ve diğ.'ne (2016) göre ise bireylerin sahip oldukları koşullar, bireylerin işyerlerindeki üretimini, kişisel sağlığını ve öğretim kalitesini etkilemektedir. Stres yaşayan bireylerde güven ve güdülenme kaybı, yönetme eksiklikleri, yabancılaşma hisleri, yetersizlik, içedönüklüğün artması, sinirlilik, işbirliğine karşı isteksizlik gibi etkiler görülmektedir. Duygusal olarak tükenmişlik yaşayan yöneticilerde iş yapmaya yönelik gereksinimlerde enerji azalması meydana gelmekte ve meslektaşlarına karşı 
sinik ilgilerin gelişmesine yol açmaktadır. Kısacası işlerindeki memnuniyetsizlikleri artmakta ve kişisel başarıları düşmektedir (Fernet, Guay, Senecal ve Austin, 2012).

Bununla birlikte katılımcıların büyük çoğunluğu, kendi bireysel kararları doğrultusunda istifa ettiklerini vurgulamışlardır. Bir kısmı ise arkadaş çevresinin, aile bireylerinin ve diğer müdür yardımcısı meslektaşlarının istifa kararı almalarında etkili olduklarını öne sürmüşledir. Elde edilen sonuca göre yönetici kıdem yılı düştükçe müdür yardımcılığından ayrılma davranışında bireysel, içsel süreçlerin ve arkadaşmeslektaş etkisinin daha baskın olduğu görülürken, ilerleyen kıdem yıllarında ise ailenin baskı öğesi olarak ortaya çıktığı görülmüştür.

Müdür yardımcılığından istifa eden öğretmenlerin büyük çoğunluğu, öğretmenliğe döndüklerinde rahatlama, mutluluk yaşadıklarını, sorumluluklarının azaldığını ve ailelerine ve kendilerine daha fazla zaman ayırabildiklerini belirtmişlerdir. Aynı zamanda öğretmenliğe döndüklerinde öğrencilerle tekrar buluşmalarının kendilerine mutluluk verdiğini, iş doyumlarının arttığını, eski rollerinin öğretmenliğe uyumunu kolaylaştırdığını vurgulamışlardır. Ayrıca, öğretmenliğe döndüklerinde bakış açılarında değişmeler yaşandığını, kişisel gelişimlerine daha fazla zaman ayırdıklarını ve sınıf içerisinde bağımsız hareket etme alanı kazandıklarını, stres ve kaygılarının azaldığını, maddi anlamda iyileşme yaşadıklarını öne sürmüşlerdir. Bu bağlamda, Kılınç, Koşar, Er ve Koşar (2017), öğretmenliğe dönen yöneticiler üzerinde yaptıkları araştırmada, yönetici iken öğretmenlerden beklediği rol ve davranışları, öğretmenliğe dönüş sonrası kendilerinden beklenenleri daha iyi bilmeleri ve ona göre davranmaları konusunda öğretmenliğe dönen yöneticilerin, orta ve üst düzeyde beklentileri gerçekleştirdiklerini, öğretmenliğe dönüş sonrası kendilerine, ailelerine, öğrencilerine daha fazla vakit ayırdıklarını ve iş yükünün azalmasından dolayı memnun olduklarını belirlemişlerdir. Bu yönüyle araştırma bulgularıyla paralellik göstermektedir.

Araştırmada, müdür yardımcılığından istifa eden katılımcıların büyük çoğunluğu öğretmenliğe döndüklerinde olumsuz bir şey yaşamadıklarını vurgulamışlardır. Fakat az sayıda katılımcı da öğretmenliğe dönüş sonrası uyum sorunu yaşadıklarını, rol değişikliğinde ve sınıf yönetiminde zorluk yaşadıklarını, hareket alanlarının daraldığını, prestij kaybı yaşadıklarını ve çevresi tarafından yetersiz olarak algılandıklarını öne sürmüşlerdir. Kılınç ve diğ. (2017) de öğretmenliğe dönen yöneticilerin dönüş sonrası çoğunlukla sınıf yönetimi, dersi planlama vb. konularda pek fazla sorun yaşamadıklarını fakat bazılarının sınıfa hâkim olma, disiplini sağlama, ders programına uyum konularında eksiklikler ve sorunlar yaşadıklarını ve diğer öğretmenlerle iletişim kurarken yönetici gibi davranma eğilimlerinin olduğunu, okul yönetimiyle fikir ayrılığı yaşadıklarını belirlemiştir. Bu bulgular bu araştırmanın bulgularını destekler niteliktedir.

$\mathrm{Bu}$ araştırmanın katılımcılarının büyük çoğunluğu (12 / 21), müdür yardımcılığına geri dönmeyi düşünmediklerini belirtmektedir. Geri dönmeyi isteyenlerin büyük çoğunluğunun (1-3 yıl) yönetici deneyim aralığında olması, bu kişilerin gerekli deneyimleri sağlamadıkları düşüncesine sahip olduklarını, bu 
anlamda pişmanlık hissettikleri ve geri dönmeyi düşündükleri sonucuna ulaşılabilir. Yine belirtilen görüşlere bakıldığında geri dönmeyi düşünmeyen öğretmenler, daha çok maaş, izin, kariyer gibi dışsal güdülenme beklentilerine sahipken; geri dönmeyi düşünen öğretmenler ise daha çok içsel güdülenmeleri doğrultusunda (hedeflerini gerçekleştirme gibi) işler ve planlamalar yapmak istemektedir. Bu açıdan bakıldığında da bir farklılık göze çarpmaktadır.

Ayrıca, müdür yardımcılığından istifa eden öğretmenlerin büyük çoğunluğunu erkek ögrretmenler (13 / 21) oluşturmaktadır. Fakat Başol (2013), kadın okul yöneticilerindeki duygusal tükenmişliğin erkek yöneticilere göre daha fazla olduğunu; Dağlı (2006), kadın okul yöneticilerinin erkek okul yöneticilerine göre daha fazla tükenmişlik ve duyarsızlaşma yaşadıklarını; Kruger ve diğ. (2005) ise kadın yöneticilerin erkek yöneticilere göre daha erken bıraktıklarını, çevresindeki risk öğeleri oluşur oluşmaz erkek meslektaşlarına göre bu risk öğelerinin kadın yöneticileri daha fazla etkilediğini belirlemişlerdir. Bu yönüyle, yapılan diğer araştırmalardan farklı bir sonuç elde edilmiştir.

Bununla birlikte müdür yardımcılığından istifa eden öğretmenlerin büyük çoğunluğu (13 / 21), 1000-1999 arası öğrenci sayısı olan ve çoğunluğu (16 / 21), 31 70 arası öğretmen sayısının olduğu okullarda görevlerinden ayrılmışlardır. Bu durum öğrenci ve öğretmen sayısının artmasının iş yükü oluşturmasına neden olduğunu ve istifa etmede önemli bir etken olduğunu göstermektedir. Ayrıca araştırmaya katılanların çoğunluğu (11 / 21) yöneticilik deneyimini yaşadıkları ilk (birinci) okullarında istifa etmeleri de yöneticiliğin ilk yıllarının zorlukları ile ilişkili olup bu anlamda devam edip etmeme kararının odak noktasını oluşturmaktadır. Bununla birlikte katılımcıların büyük çoğunluğu (15/21) 11 yıl ve üstü öğretmenlik kıdem yılına sahiptir. Bu anlamda ilerleyen kıdem yıllarında öğretmenlik daha çekici duruma gelmekte ve iş doyumunun yönü yönetsel süreçlerden çok sinıftaki öğrenci öğrenmelerine yönelmektedir. Bu açıdan bakıldığında yöneticilik deneyim yılı ile öğretmenlik deneyim yılının, yöneticiliği bırakma anlamında ters orantılı bir süreç izlediği yadsınamaz. Nitekim bu araştırmada görüldüğü gibi müdür yardımcılığından istifa edenlerin çoğu, yöneticilik deneyiminin ilk üç yılında iken öğretmenlikteki deneyimleri 11 yıl ve üstündedir.

Bütün bu bulgular 1şı̆̆ında politika yapıcılar ve karar vericilere; okul müdür yardımcılığ ve kariyer geçiş basamağı olarak yerini alması, müdür yardımcılarının özlük haklarının iyileştirilmesi önerilmektedir.

Okul müdürlerine; karar alma süreçlerinde müdür yardımcılarının fikirlerinin dikkate alınması, görev ve sorumlulukların dağıtılmasında eşitlik ve bireye uygunluk ilkesine dikkat edilmesi, müdür yardımcılarını kaygıya ve strese yönlendiren uyarıcı ve ortamların ortadan kaldırılması için çaba gösterilmesi önerilmektedir. 
Araştırmacılara ise; okul müdür yardımcılarının daha çok mesleğin ilk yıllarında istifa etmeleri nedeniyle bu dönemi başarılı bir şekilde atlatabilmeleri yönünde araştırmalar yapmaları önerilmektedir.

\section{Kaynakça}

Allen, J. G., and Weaver, R. L. (2014). Learning to lead: The professional development needs of assistant principals. NCPEA Education Leadership Review, 15(2), 14-32. Retrieved from https://files.eric.ed.gov/fulltext/EJ1105575.pdf

Bakioğlu, A. (1994). Okul yöneticisinin kariyer basamakları: İngiliz eğitimi sisteminde yöneticilerin etkinlikleri üzerindeki faktörler. Marmara Üniversitesi Atatürk Eğitim Fakültesi Eğitim Bilimleri Dergisi, (6), 17-28. http://dspace.marmara.edu.tr/bitstream/handle/11424/3727/1099-2064-1SM.pdf?sequence $=1 \&$ isAllowed=y adresinden edinilmiştir.

Barnett, B. G., Shoho, A. R., and Oleszewski, A. M. (2012). The job realities of beginning and experienced assistant principals. Leadership and Policy in Schools, 11(1), 92-128. doi: 10.1080/15700763.2011.611924

Başol, G. (2013). A comparison of female and male school administrators' burnout levels controlling for perceived social support. Education and Science,38(169), 3-18. Retrieved from http://egitimvebilim.ted.org.tr/index.php/EB/article/view/372/490

Burkhauser, S., Gates, S. M., Hamilton, L. S., and Ikemoto, G. S. (2012). Challenges and opportunities facing principals in the first year at a school (Report No. RB9643-NLNS). California: RAND Corporation. Retrieved from https://www.rand.org/pubs/research_briefs/RB9643.html

Calman, R. C. (2010). Exploring the underlying traits of high-performing schools. Toronto, Canada: Education Quality and Accountability Office.

Cano-García, F. J., Padilla-Muñoz, E. M., and Carrasco-Ortiz, M. A. (2005). Personality and contextual variables in teacher burnout. Personality and Individual Differences, (38), 929-940. doi: 10.1016/j.paid.2004.06.018

Collinson, V., and Cook, T. F. (2007). Organizational learning: Improving learning, teaching, and leading in school systems. Thousand Oaks, CA: Sage.

Creswell, J. W. (2013). Nitel araştırma yöntemleri [Qualitative inquiry \& research design: Choosing among five approaches]. (M. Bütün ve S. B. Demir, Çev.). Ankara: Siyasal Kitapevi. (Orijinal kitabın yayım tarihi 2013)

Dağlı, A. (2006). Okul yöneticilerinin tükenmişlik düzeyleri. Eurasian Journal of Educational Research, (25), 85-95. 
Daresh, J. C., and Playko, M. A. (1994). Aspiring and practicising principals; perceptions of critical skills for beginning leaders. Journal of Educational Administration, 32(2), 35-45. doi: 10.1108/09578239410063102

Darmody, M., and Smyth, E. (2008). Job satisfaction and occupational stress among primary school teachers and school principals in Ireland. Retrieved from http://www.teachingcouncil.ie/en/Publications/Research/Documents/Job-

Satisfaction-and-Occupational-Stress-among-Primary-School-Teachers-andSchool-Principals-in-Ireland.pdf

Demarest, E. J. (2011). A learning-centered framework for education. New York, NY: Teachers College Press.

Dlugosh, L. L. (1994). Why administrators move: Factors contributing to the turnover of school administrators in Nebreska (Research Report No. 143). Retrieved from http://files.eric.ed.gov/fulltext/ED375505.pdf

Erginer, A. ve Köse, M. F. (2012). Okul yöneticilerinin yöneticiliği tercih ve bırakma nedenlerine ilişkin nitel bir çalışma. E-Journal of New World Sciences Academy, 7(4), 14-28. http://dergipark.gov.tr/download/article-file/187033 adresinden edinilmiştir.

Fenwick, L. T. (2000). The principal shortage: Who will lead? Cambridge, MA: Harvard Principals' Center.

Fernet, C., Guay, F., Senecal, C., and Austin, S. (2012). Predicting 1ntraindividual changes in teacher burnout: The role of perceived school environment and motivational factors. Teaching and Teacher Education, 28(4), 514-525. doi: 10.1016/j.tate.2011.11.013

Fields, L., and Egley, R. (2005). Assistant principals in Florida rank first-year challenges; Study's results highlight areas of need for professional development. ERS Spectrum, 23(1), 4-10.

Fink, D. (2010). The succession challenge: Building and sustaining leadership capacity through succession management. Thousand Oaks, CA: Sage.

Friedman, I. A. (2002). Burnout in school principals: Role related antecedents. Social Psychology of Education, (5), 229-251. Retrieved from https://www.researchgate.net/profile/Isaac_Friedman/publication/225636119_ Burnout_in_School_Principals_Role_Related_Antecedents/links/5b34d169a6f dcc8506d79eee/Burnout-in-School-Principals-Role-Related-Antecedents.pdf

Gajda, R., and Militello, M. (2008). Recruiting and retaining school principals: What We can learn from practicing administrators. Journal of Scholarship and Practice, 5(2), 14-20. Retrieved from https://www.aasa.org/uploadedFiles/Publications/Journals/AASA_Journal_of_ Scholarship_and_Practice/Summer08FINAL093008.pdf 
Glanz, J. (1994). Redefining the roles and responsibilities of assistant principals. Clearing House, 67(5), 283-287. doi: 10.1080/00098655.1994.9956089

Gmelch, W. H., Gates, G., Parkay, F. W., and Torelli, J. A. (1994, April). The impact of personal, professional, and organizational characteristics on administrator burnout. Report Presented at the Annual Meeting of the American Educational Research Association, New Orleans. Retrieved from http://files.eric.ed.gov/fulltext/ED373451.pdf

Göksoy, S. (2015). Bureaucratic problems at schools. Journal of Education and Future, (7), 99-118. Retrieved from https://dergipark.org.tr/download/articlefile/174211

Gray, C., and Behan, S. (2005). Current and predicted staffing patterns in postprimary schools: The perception and experience of school principals. Oxford Review of Education, 31(3), 443-458. doi: 10.1080/03054980500222189

Green, R. L. (2010). The four dimensions of principal leadership: A framework for leading 21st century schools. Boston, MA: Allyn \& Bacon.

Günay, G. ve Özbilen, F. M. (2018). Öğretmenlerin okul yöneticiliği istekliliğini etkileyen faktörlerin belirlenmesi. Turkish Studies Educational Sciences, 13(19), 1331-1344. doi: 10.7827/TurkishStudies. 14069

Hart, A. (1993). Principal succession: Establishing leadership in schools. Albany: SUNY Press.

Harvey, M. J. (1994). The deputy principalship: Retrospect and prospect. The International Journal of Educational Management, 8(3), 15-25. doi: $10.1108 / 09513549410062407$

Hausman, C., Nebeker, A., McCreary, J., and Donaldson, G. (2001). The worklife of the assistant principal. Journal Of Educational Administration, 40(2), 136-157. doi: 10.1108/09578230210421105

Hayon, L., Faraj, H., and Wubbels, T. (2001). Burnout among Israeli Arab school principals as a function of professional 1dentity and interpersonal relationships with teachers. International Journal of Leadership in Education. 5(2), 149-162. doi: 10.1080/13603120110057091

Jonga, D., Grundmeyer, T., and Yankey, J. (2017). Identifying and addressing themes of job dissatisfaction for secondary principals. School Leadership and Management, 37(4), 354-371. doi: 10.1080/13632434.2017.1338253

Karahan, M. (2019). İlköğretim okulu yöneticilerinin yetki kullanımında ve yetki devrinde yaşadıkları sorunlar (Kars ili örneği). Avrasya Sosyal ve Ekonomi Araştırmalarl Dergisi (ASEAD), 6(3), 345-380. https://dergipark.org.tr/download/article-file/678287 adresinden edinilmiştir. 
Kılınç, A. Ç., Koşar, S., Er, E. ve Koşar, D. (2017). Okul yöneticiliği görevinden öğretmenliğe dönüş: Yaşanan sorunlar ve çözüm önerileri. Türk Bilim Araştırma Vakfi, 10(3), 53-73. https://dergipark.org.tr/download/article-file/340785 adresinden edinilmiştir.

Konan, N., Yılmaz, S. ve Bozanoğu, B. (2017). Okul müdür yardımcisı görevlendirilmesine ilişkin yönetici ve öğretmen görüşleri. Kuram ve Uygulamada Eğitim Yönetimi Dergisi, 23(1), 105-134. doi: 10.14527/kuey.2017.004

Koşar, S., Sezgin, F. ve Aslan, H. (2013). Okul müdürlerinin resmî görev tanımlarının dışında olduğunu düşündükleri işlere ilişsin görüşleri. GEFAD (Gazi Eğitim Fakültesi Dergisi), 33(1), 147-164. http://www.gefad.gazi.edu.tr/download/article-file/76919 adresinden edinilmiştir.

Köse, A. (2018). Okul müdür yardımcılarının bakış açılarıyla okul müdür yardımcılığı görevi: Bir öz değerlendirme. Journal of Social And Humanities Sciences Research (JSHSR), 5(16),

http://www.jshsr.org/Makaleler/407632389_20_2018_5-

16.ID338.\%20Arif\%20K\%c3\%96SE_191-211.pdf adresinden edinilmiş̧ir.

Kruger, M. L., Eck, E. V., and Vermeulen, A. (2005). Why principals leave: Risk factors for premature departure in the Netherlands compared for women and men. School Leadership and Management, 25(3), 241-261 Retrieved from http://www.tandfonline.com/doi/abs/10.1080/ 13634230500116 322

Lacey, K. (2002). Avoiding the principalship. Principal Matters, 53, 25-29.

Manabete, S. S., John, C. A., Makinde, A. A., and Duwa, S. T. (2016). Job stress among school administrators and teachers in Nigerian secondary schools and technical colleges. International Journal of Education, Learning and Development, 4(2), 1-9. Retrieved from https://www.researchgate.net/profile/Abraham_Makinde/publication/32760108 7_Job_Stress_among_School_Administrators_and_Teachers_in_Nigerian_Sec ondary_Schools_and_Technical_Colleges/links/5c2be75c458515a4c7065c9e/J ob-Stress-among-School-Administrators-and-Teachers-in-Nigerian-SecondarySchools-and-Technical-Colleges.pdf

Michel, G. J. (1996). Socialization and career orientation of the assistant principal. Retrieved from https://files.eric.ed.gov/fulltext/ED395381.pdf

Millî Eğitim Bakanlı̆̆ı Okul Öncesi Eğitim ve İlköğretim Kurumları Yönetmeliği. (2014). Resmi Gazete, 29072, 26 Temmuz 2014. 
Özalp, U., Yirci, R. ve Kocabaş, İ. (2016). Müdür yardımcılarının iş doyumunun yordayıcısı olarak okul müdürlerinin mentorluk fonksiyonları. Kalem Eğitim ve Insan Bilimleri Dergisi, 6(2), 455-494. http://kalemacademy.com/Cms_Data/Contents/KalemAcademyDB/Folders/Sa yiMakaleleri/ contents/G7726MJNBZB8M2SG/2016-kalemueibd-11kissayisi-makale-005-11.pdf adresinden edinilmiştir.

Patton, M. Q. (2014). Nitel araştırma ve değerlendirme yöntemleri [Qualitative research \& evaluation methods] (3. Baskıdan Çeviri). (M. Bütün, S. B. Demir, Çev. Ed.). Ankara: Pegem Akademi. (Orijinal kitabın yayım tarihi 1990)

Reeves, J., Moos, L., and Forrest, J. (1998). The school leader's view. In J. Macbeth, (Ed.), Effective school leadership (pp. 32-59). London, UK: Paul Chapman/Sage.

Searby, L., Browne-Ferrigno, T., and Wang, C. (2016). Assistant principals: Their readiness as instructional leaders. Leadership And Policy In Schools, 16(3), 397430. doi: 10.1080/15700763.2016.1197281

Shen, J., Cooley, V. E., and Ruhl-Smith, C. D. (1999). Entering and leaving school administrative positions. International Journal of Leadership in Education, 2(4), 353-367. doi: 10.1080/136031299292922

Shoho, A. R., and Barnett, B. G. (2010). The realities of new principals: challenges, joys and sorrows. Journal of School Leadership, 20(5), 561-596. doi: $10.1177 / 105268461002000503$

Spillane, J. P., and Lee, L. C. (2014). Novice school principals' sense of ultimate responsibility: Problems of practice in transitioning to the principal's office. Educational Administration Quarterly, 50(3), 431-465. doi: 10.1177/0013161X13505290

Turan, S. ve Yalçın, G. (2015). Okul yöneticilerinin yaptığı ve yapmak istediği işler ile iş doyumları arasındaki ilişkinin incelenmesi. Kalem Ĕgitim ve İnsan Bilimleri Dergisi, 5(2), 11-34. http://kalemacademy.com/Cms_Data/Sites/KalemAcademy/Files/KalemAcade myRepository/sayilar/Sayi9_01OkulYoneticilerininYaptigi.pdf adresinden edinilmiştir.

Türkmenoğlu, G. ve Bülbül, T. (2015). Okul yöneticilerinin göreve geliş biçimlerinin okul kültürüne yansımaları. Mersin Üniversitesi Eğitim Fakültesi Dergisi, 11(2), 526-549.

Webb, R., and Vulliamy, G. (1995). The changing role of the primary school deputy headteacher. School Organization, 15(1), 53-64. doi: 10.1177/0263211X9602400307 
Weindling, D. (2000, April). Stages of headship: A longitudinal study of the principalship. Paper presented at the American Educational Research Association, New Orleans, LA.

Yazıcıoğlu, Y. ve Erdoğan, S. (2004). Spss uygulamalı bilimsel araştırma yöntemleri. Ankara: Detay Yayıncilık.

Yıldırım, A. ve Şimşek, H. (2011). Sosyal bilimlerde nitel araştırma yöntemleri. Ankara: Seçkin Yayıncılık. 


\title{
The Reasons Why School Assistant Principals Leave Their Careers ${ }^{1}$
}

\begin{tabular}{cccc}
\hline ARTICLE TYPE & Received Date & Accepted Date & Published Date \\
Research Article & 12.29 .2018 & 10.04 .2019 & 10.04 .2019 \\
\hline
\end{tabular}

\author{
Mesut Demirbilek (iD ${ }^{2}$ and Ayşen Bakioğlu (iD) ${ }^{3}$ \\ Marmara University
}

\begin{abstract}
The purpose of the study is to examine the reasons why assistant principals leave their positions voluntarily. The phenomenology pattern, which is one of the qualitative research methods, was used in data analysis and the data were collected using a semi-structured interview form. Through the criterion sampling method, 21 teachers who had resigned from the assistant principal positions and turned back to teaching positions in different districts of Istanbul were interviewed. The data obtained from the interviews were coded and subjected to content analysis under themes. In the study, it was observed that most of the people who resigned from assistant principal positions were male and they resigned in the beginning phase of their careers (1-3 years). Most of those who resigned were elementary school teachers and most of them resigned from the school with 1000-1999 students and 31-70 teachers. At the same time, most of them resigned in the first three years of their managerial positions and 11 years or more of their teaching positions. The majority of those who resigned from assistant principal positions stated that administrative paperwork was too much, they had been engaged in non-duty jobs, they had been forced to encounter recruitment interviews and political-ideological barriers and they did not consider the assistant principal position as a career. As an external factor, family factors were observed to be effective in resigning. When the internal factors were examined, the following reasons were observed: workload, having difficulty in having teachers and other staff make things, being caught in the middle of the principal and the teachers, the littleness of the income of the assistant principal position, minimum annual leave, being obliged to use less time than the annual leave period and long working hours. At the same time, they stated that they were experiencing mental-emotional exhaustion in the assistant principal position and that the majority of them $(12 / 21)$ did not consider returning to that position. In this respect, it is noteworthy for the research that the factors within the school and career rights are more dominant in terms of reasons for and dimensions of resignation.
\end{abstract}

Keywords: Assistant principals, resignation, manager, career, assistant principals career.

${ }^{1}$ This paper was presented at the International Learning, Training and Education Research Congress: 6-8 September 2018, Amasya, Turkey.

${ }^{2}$ Corresponding Author: PhD Student, Ataturk Faculty of Education, Departmant of Educational Administration and Supervision, E-mail: demirbilekmesut@gmail.com, https://orcid.org/0000-00027570-7807

${ }^{3}$ Prof. PhD., Ataturk Faculty of Education, Departmant of Educational Administration and Supervision Faculty, E-mail: abakioglu@ @armara.edu.tr, https://orcid.org/0000-0002-2571-1533 


\section{Purpose and Significance}

The duties that school administrators have to deal with are very diverse. There are many areas they work on such as finance management, being responsible for directing and coordinating teaching, and communicating with external stakeholders and families. At the same time, the school administrators, who have responsibilities for staff management and all legal issues, are also responsible for the coherence between teaching methods and student learning as required by their pedagogical role. On the other hand, school administrators must cooperate with the educational bureaucracy and other support components in the background of the school and play a pioneering role in implementing innovations (Friedman, 2002). Because the position of assistant principal is the first official school leadership for a teacher having new duties and challenges that he / she did not experience in teachers' roles, teachers face difficulties in balancing their personal and professional lives due to the numerous and varied responsibilities required by this role (Fields and Egley, 2005; Hausman, Nebeker, McCreary and Donaldson, 2001). Michel (1996) defines this change as moving from an isolated classroom environment to a more open and interactive administrative atmosphere. Barnett, Shoho and Oleszewski (2012) emphasize that the role of assistant principals should evolve from a traditional disciplinary and executive perspective to a perspective where the development of the school's curriculum comes to the forefront as schools face academic performance demands and in this sense, the job descriptions become more complex. The special roles and duties of the assistant principals include not only reducing the burden of the principals but also providing administrative support to the teachers and dealing with the welfare of the students. In addition, many job descriptions of assistant principals are not clear and the responsibilities of assistant principals may vary between schools and districts (Glanz, 1994; Harvey, 1994). For example, assistant principals in England and Wales described their responsibilities as ridiculous, mind-blowing, impossible and frustrating (Webb and Vulliamy, 1995). In this sense, there are negativities and decreases in the roles of school administrators due to the pressure elements emerging in and outside the school and this situation creates stress, anxiety, and pressure that may extend to giving up career goals. School administrators think that they cannot meet their performance expectations about their duties and they may feel disappointed, exhausted and unsuccessful. Some of them think about giving up school management while others learn to fight or endure loads imposed on them by their work (Friedman, 2002). In this respect, it is important to examine the reasons why the assistant principals resign. The purpose of this study is to investigate the reasons for the separation of assistant school principals who left their positions voluntarily.

\section{Method}

The research was carried out with the phenomenology pattern, which is one of the qualitative research methods. Phenomenology pattern focuses on the facts that we are aware of but do not have an in-depth and detailed understanding (Patton, trans. 2014; Yıldırım ve Şimşek, 2011). The criterion sampling method, which is one of the 
purposive sampling methods, was used to determine the study group. The main purpose of the criterion sampling method is to study the situations based on a predetermined criterion. This criterion can be created by the researcher or a list of previously prepared criteria can be used (Yıldırım and Şimşek, 2011). In our study, the main criterion constituting the study group is the school assistant principals in public schools who resigned from their positions. A total of 21 teachers from public schools in Çekmeköy, Sancaktepe, Ümraniye, Üsküdar, Kartal and Ataşehir districts on the Anatolian side of Istanbul were interviewed. All of these are the teachers who were previously assistant principals and resigned from their positions voluntarily. The interview technique was used to collect the data. In order to find out the opinions and experiences of the teachers about the reasons for resigning from their assistant principal positions, a semi-structured interview form consisting of 11 open-ended questions, which was prepared after the review of the literature, was used. The interviews were conducted in November-December 2017 and face to face. During the interview, the participants were informed about the interview and the recording device was used with permission in order to prevent data loss. The content analysis technique was used in the analysis of research data. The audio recordings obtained from the interviews were transcribed and opinions were grouped under similar topics. The opinions were coded and then the codes were analyzed under certain categories and themes.

\section{Results}

According to the results of the study, the majority of the teachers who resigned from the assistant principal position emphasized that the administrative paperwork was too much. At the same time, they stated that they were dealing with non-duty jobs, there was inequality in the distribution of duties, and the job descriptions were not clear and appropriate for them. Also, the majority of the assistant principals who resigned stated that the reasons for resigning from the assistant principal position were family and family-related factors as the external factor and the workload and work intensity as an in-school factor. At the same time, they stated that the problems of student behavior, financial impossibilities, and inadequacies of the school, negative effect of the principal, the parents and teachers, lack of personnel, continuous change of staff, high number of students and teachers, inexperience of the principals and inability to manage the resources effectively in school were also influential. In addition, the majority of assistant principals stated that they had difficulties in having teachers and other staff members make things. Teachers also indicated that there was no equity in awarding, the principal had a repressive attitude, they were caught in the middle of the teachers and the principal, the school principal was inexperienced and inadequate, the school principal discriminated, and also the school principal felt that their positions are shaken because of more attention to assistant principals. Furthermore, the majority of the assistant principals stated that this position had no economic benefits, the assistant principals had a limited number of annual leave and they could not use them most of the time, they had long working hours and they were responsible for everything in the school. At the same time, the majority of the resigned 
assistant principals stated that they had experienced mental and emotional tiredness and exhaustion in the role of assistant principals. In addition, these teachers stated that they could not spare time for themselves as assistant principals, they experienced hopelessness, they perceived inadequacy, their motivation decreased, and they had problems of adaptation to school. These teachers, who stated that the atmosphere did not meet their expectations, added that their job satisfaction decreased and they resigned in order to avoid conflict. The majority stated that they resigned in line with their individual decisions and they did not want to return to their assistant principal positions.

\section{Discussion and Conclusions}

In the study, the majority of the participants of the study group resigned from the position at the beginning of their careers. According to Darmody and Smyth (2008), while job satisfaction of school principals increases in the first years of their career, especially in 4-6 years period, there is a decrease in job satisfaction and then it increases again in the following years. In this sense, it differs from our research. However, the small number of those with high managerial experience years among those who resigned can be explained by Darmody and Smyth's (2008) increasing job satisfaction as the career progresses. In a study conducted by RAND company in the United States in six regions, many school principals had to leave in the first year or second year of their profession. Even more than fifty percent of the participants left their positions in the first two years of their professions (Burkhauser, Gates, Hamilton and Ikemoto, 2012). According to Bakioğlu (1994), the school principals in the initial phase change the value judgments adopted in the previous period and the administrators in the initial phase see the problems related to the day-to-day operations, public relations, school curricula, and parents as big difficulties, feel themselves in uncertainty and spend a lot of time learning the information about their field of duty. At this stage, confusion occurs due to the diversity of roles and is considered the most difficult period by the managers. In this sense, the findings support the results of the research. Male managers (13/21) constituted the majority of those who resigned from the assistant principals. However, Başol (2013) found that emotional burnout in female school administrators is more common than male managers. Dağlı (2006) found that female school administrators experienced more burnout and depersonalization than male school administrators did. In addition, Kruger, Eck, and Vermeulen (2005) found that female managers left earlier than male managers and risk factors in their workplace affected them more than their male counterparts as soon as risk factors occurred. In this respect, some differences were found with the literature. In the light of all these findings, it is recommended that policymakers and decision-makers should improve the efficiency of the schools, achieve the determined goals, ensure the national-international competition, pay attention to merit elements in the management appointment system, and introduce a long-term executive appointment system based on objective, individual qualities, and performance. 
